\title{
VASCULAR FLORA OF A PART OF THE PLANNED HRVATSKO ZAGORJE REGIONAL PARK (NORTHWESTERN CROATIA)
}

\author{
Dario Hruševar ${ }^{1}$, Petra Siladi ${ }^{2}$, Marta Justić ${ }^{1}$ \& Božena Mitić ${ }^{1, *}$ \\ ${ }^{1}$ University of Zagreb, Faculty of Science, Department of Biology, \\ Rooseveltov trg 6, 10000 Zagreb, Croatia \\ ${ }^{2}$ Agricultural High School Križevci, Milislava Demerca p.p.1., 48260 Križevci, Croatia
}

\begin{abstract}
Hruševar, D., Siladi, P., Justić, M. \& Mitić, B.: Vascular flora of a part of the planned Hrvatsko zagorje Regional park (northwestern Croatia). Nat. Croat., Vol. 27, No. 2, 271-292, 2018, Zagreb.

The wild vascular flora of the area in the northwestern part of Croatia - Hrvatsko zagorje (near the settlements of Cerje Jesenjsko, Šaša, Pašnik, Vrbno and Ježovec, along with the related hamlets) was explored during the vegetation season of 2011. So far, no floristic data have been recorded for this area, planned to be a part of the future Hrvatsko zagorje Regional Park. On the area of about $4 \mathrm{~km}^{2}, 389$ vascular plant species (which belong to 77 families) were noticed. The most abundant families are Fabaceae (9.3\%), Poaceae (7.7\%), Asteraceae (7.5\%), Lamiaceae $(6.2 \%)$ and Rosaceae $(5.1 \%)$. The spectrum of life forms indicates the dominance of hemicryptophytes $(50.4 \%)$, and the most prominent chorological type is Eurasian (55.0\%). The share of urbanophobic and invasive taxa as well as the values of indicators of anthropogenic changes in the researched flora indicate that the investigated area shows semi-natural character, with weak to moderate anthropogenic pressure. Although the share of endemic, endangered and protected taxa is low, the diversity of other native plants justifies protection of the researched area at the level of a regional park.
\end{abstract}

Keywords: floristic analysis, indicators of anthropogenic changes

Hruševar, D., Siladi, P., Justić, M. \& Mitić, B.: Vaskularna flora dijela planiranog regionalnog parka Hrvatsko zagorje. Nat. Croat., Vol. 27, No. 2, 271-292, 2018, Zagreb.

Samonikla vaskularna flora dijela Hrvatskog zagorja (okolica naselja Cerje Jesenjsko, Šaša, Pašnik, Vrbno i Ježovec s pripadajućim zaselcima) u sjeverozapadnom dijelu Hrvatske istražena je tijekom vegetacijske sezone 2011. godine. Za ovo područje, koje se nalazi unutar planiranog Regionalnog parka Hrvatsko zagorje, nisu do sada bili zabilježeni nikakvi floristički podaci. Na području veličine oko $4 \mathrm{~km}^{2}$ zabilježeno je ukupno 389 svojti vaskularne flore, svrstanih u 77 porodica. Najzastupljenije porodice su Fabaceae (9,3\%), Poaceae (7,7\%), Asteraceae $(7,5 \%)$, Lamiaceae $(6,2 \%)$ te Rosaceae $(5,1 \%)$. Spektar životnih oblika ukazuje na dominantnost hemikriptofita $(50,4 \%)$, a najzastupljeniji geoelement je euroazijski $(55,0 \%)$. Udio urbanofobnih i invazivnih svojti, kao i vrijednosti indikatora antropogenih promjena flore ukazuju da istraživano područje pokazuje poluprirodni karakter sa slabim do umjerenim antropogenim pritiskom. Iako je udio endemičnih, ugroženih i zaštićenih svojti nizak, raznolikost ostalih autohtonih biljaka opravdava zaštitu istraživanog područja na nivou regionalnog parka.

Ključne riječi: florističke analize, indikatori antropogenih promjena 


\section{INTRODUCTION}

Hrvatsko zagorje is a hilly area in the northwestern part of Croatia. Although the borders of this region are not clearly defined either geographically or administratively, the opinion of most experts as well as of the population of this area is that Hrvatsko zagorje extends between the Sutla River and the Mountains of Medvednica, Kalnik, Varaždin and Macelj (PoLJAK, 2007). Most of this area is covered with fields, vineyards and scattered villages, with forests stretched around. On the hill slopes there are relatively small areas of lawns, while in the river valleys there are much larger areas covered with meadow vegetation (STANČić, 2000). Around $400 \mathrm{~m}$ above the sea level are areas of large forests without settlements (ČAPLAR, 2011). Based on its natural and cultural richness, this area is included in the Strategy and Action Plan for the Protection of Biological and Landscape Diversity of the Republic of Croatia. It is also planned that it become a part of the Hrvatsko Zagorje Regional Park (AnONYmous, 2007).

Although according to the Flora Croatica Database (NiкоLıć, 2018) no floristic data have been recorded for the researched area, Croatian Zagorje is more or less well-researched in this respect, especially the areas of Strahinščica and Krapina. However, most of these data are quite old, so any new research is very desirable, especially because of the plan to proclaim part of Hrvatsko Zagorje a regional park. Older floristic data are provided by Ljudevit Gaj (list of plant species for the wider area of Krapina in 1826), Schlosser and Vukotinović (botanical observations in the area of Krapina, Macelj and Trakošćan in 1853), while Hirc (during the years 1915 and 1916) elaborated in detail the flora of Krapina and its surroundings, Strahinščica, Maceljsko gorje, Trakošćan and Ravna gora (all previous quotes according to HiRc, 1917). After World War I, a contribution to the flora of Hrvatsko zagorje was given by HoRvat (1929) and Horvatić (1931). Furthermore, Regula-Bevilaceua (1978) recorded a total of 1085 plant species for the Strahinščica area, and the same author returned to floristic research into Zagorje throughout the second half of the 20th century (REgula-BevilacQua, 1985, 1986, 1991, Regula-Bevilaceua \& ŠEgulja, 2000). Thereafter further floristic researches were conducted in the areas of: Konjščina (STANČIĆ, 1994), Krapinske toplice (ŠošTARIć \& MARKović, 1998), Ivančica and Ravna gora (ŠINCEK, 2003) and Ludbreg (HoRvat, 2017). Also, research into orchids in Strahinščica and the surrounding area resulted in the finding of the new species Epipactis nordeniorum Robatsch (BorovečKI-VOSKA, 2010). Floristic research continues in the second decade of the 21st century (eg, ŠINCEK et al., 2012; VeIĆ, 2015), and the flora of another area that should also be included in the planned Regional Park (the villages of Gornje and Donje Jesenje) was analysed by SALKIĆ (2012).

The aims of our work were: (1) the inventorying of the vascular flora of a part of the planned Hrvatsko zagorje Regional Park (near the settlements of Cerje Jesenjsko, Šaša, Pašnik, Vrbno and Ježovec with the accompanying villages); (2) the analysis of the recorded flora according to: taxonomic preferences, life forms, chorological types, indicators of anthropogenic influence on plants (urbanophobia / indifference / urbanophilia), chronoelement and origin (native / endemic and endangered or protected vs. alien / invasive taxa), indicators of anthropogenic changes in flora; (3) the comparison of the results with those of floristic analyses of other urban and suburban areas (if possible). 


\section{Study area}

The district investigated (Fig. 1) is about $4 \mathrm{~km}^{2}$ in area, $12 \mathrm{~km}$ north of the city of Krapina, and it encompasses the surrounding area of the settlements Cerje Jesenjsko, Šaša, Pašnik, Vrbno and Ježovec, as well as the hamlets of Kuhari, Gamilec, Horvateki, Sambolići, Brački, Juretići, Banički, Smrečki, Brezni and Strmečki. Most of it is in Varaždin County, while a smaller part belongs to Krapina-Zagorje County (Anonymous, 2014). A large part of the area is under anthropogenic influence, with a lot of cultivated areas and grazing grasslands, while the surrounding hills are covered with forest vegetation.

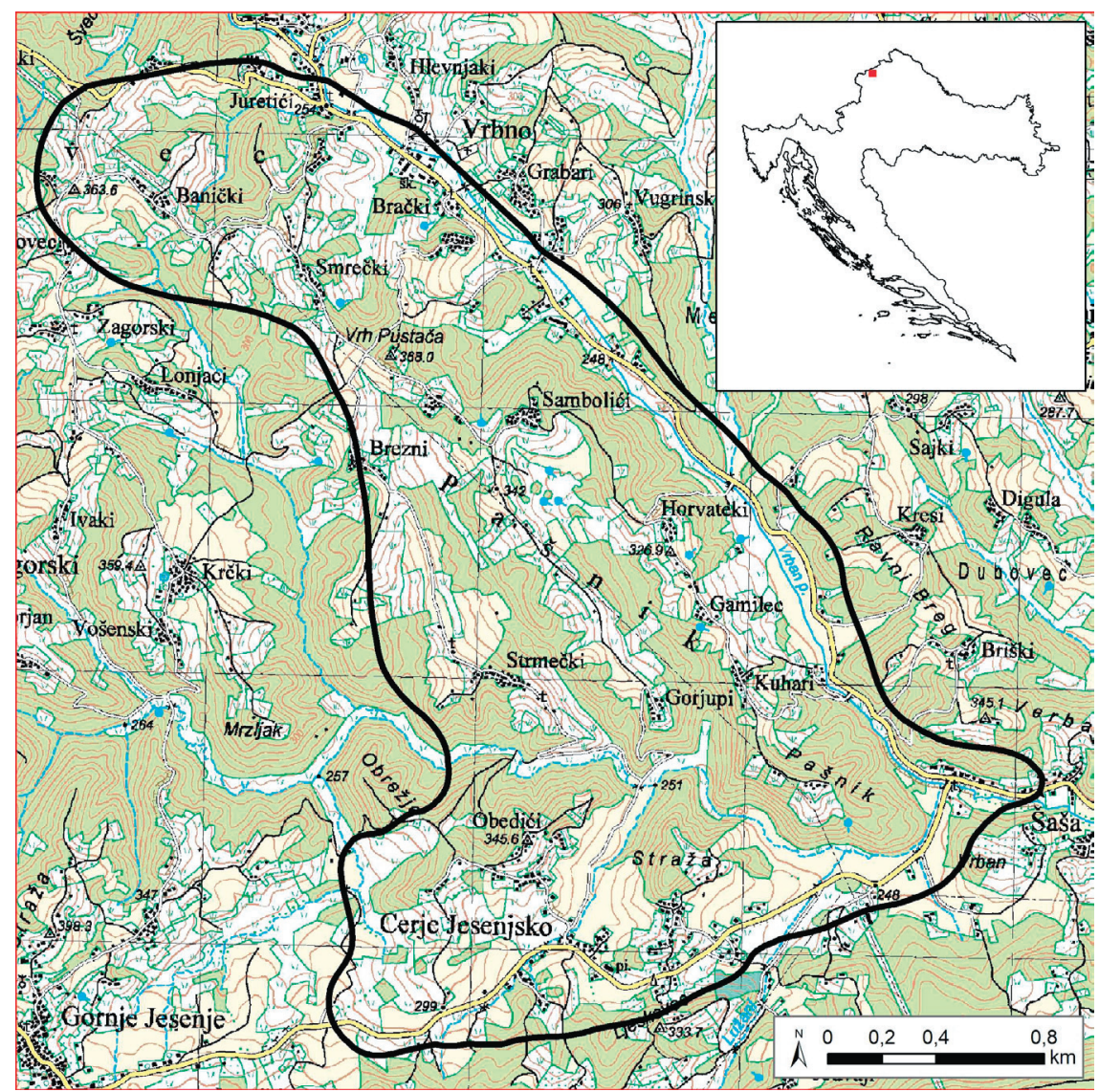

Fig. 1. Geographic position and detailed map of the researched area (a part of the planned Hrvatsko zagorje Regional park, northwest Croatia).

According to the geographical distribution of climatic types by Köppen, the climate type prevailing in the exploration area is $\mathrm{Cfb}$ - a temperate climate without dry season and with a warm summer (FILIPČIć, 1998). The coldest month of the year (January) is above $-3^{\circ} \mathrm{C}$, while the summers are fresh with the average monthly temperature of the hottest month below $22{ }^{\circ} \mathrm{C}$ (ŠEGOTA \& FILIPČIĆ, 2003). The average annual precipitation volume in the northwestern part of Croatia ranges between 900 and $1000 \mathrm{~mm}$ (AnONymous, 2008). 


\section{METHODS}

The research was carried out during the 2011 vegetation season over an area of approximately $4 \mathrm{~km}^{2}$. Findings of taxa were geocoded by a GPS device (Garmin eTrex Vista HCx). The largest number of species was determined in the field; one part of the plant material was photographed, and one part was collected for additional verification or for determination that is more precise. For this purpose, standard and specialized determination keys and iconography were used: Jermy \& Tutin (1982), Tutin et al. (1968-1980, 1993), Jávorka \& Csapody (1991), Hubbard (1992), Martinčić et al. (1999), Domac (2002), Alegro \& Bogdanović (2003) and Rothmaler \& Jäger (2007). Nomenclature of plants follows the Flora Croatica Database (Nikolić, 2018), and taxonomy is in accordance with Nikolić (2013). Next, data were attributed to each recorded taxon (Appendix 1): life forms, chorological types, indicators of anthropogenic influence, chronoelements, origin and endemism/threat/protection, if any. The abbreviations and marks used in the Appendix 1, Figs 2-5 and Tab. 1, are explained in this chapter.

Raunkier's life forms were taken from Landolt et al. (2010): Ch - chamaephytes, G - geophytes, H - hemicryptophytes, Hy - hydrophytes, P - phanerophytes, T - therophytes.

Chorological analysis was also based on LANDOLT et al. (2010), and chorological types were then grouped into one of twelve categories, according to Horvatić (1963) and Horvatić et al. (1967-1968): 1. med - Mediterranean, 2. illyr-balk - Illyrian-Balkan, 3. S-eu - South European, 4. atl - Atlantic, 5. E-eu-pont-East-European-Pontic, 6. SE-eu - Southeast European, 7. C-eu - Central European, 8. eu - European, 9. eu-as - Euro-Asian, 10. circ-holoarct - Circumholoarctic, 11. cosmop - Cosmopolites, 12. adv - Adventive and cultivated taxa.

Analysis of indicators of anthropogenic influence on plants i.e. of the share of plant taxa in relation to natural or anthropogenic habitats also follows LANDOLT et al. (2010). Based on the relationship between anthropogenic pressure and plant growth conditions we distinguish the following categories of plants: 1. extremely urbanophobic, 2. moderately urbanophobic, 3. indifferent, 4 . moderately urbanophilic, 5. extremely urbanophilic.

The chronoelement / origin of taxa (type and time of immigration) was based on Mitić et al. (2008), and terminologically modified according to Kornaś (1981), Mirek (1981) and Jаскошіак (1990). The analysis of the chronoelements is based on MedvecкÁ et al. (2012), whereas neophytes originating in Europe in our research are treated as native taxa (more precisely, Cyclamen purpurascens, Malva moschata and Rumex patientia). According to origin and chronoelement we distinguish the following groups: sp - spontaneophytes (spontaneous, native taxa), ar - archaeophytes (alien plants introduced before $1500 \mathrm{AD}$ ), kn - kenophytes (neophytes, alien plants introduced after 1500 AD) and df - diaphytes (casual alien taxa with occasional / temporary occurrence). The invasiveness of alien taxa follows Boršić et al. (2008), and is abbreviated with the mark "inv". The geographical origin of alien taxa was marked as follows: E - Europe, Af Africa, As - Asia, N Am - North America, C AM - Central America, S Am - South America.

Data on endemic taxa were taken from Nikolić (2018), and those on endangered taxa from Nikolić \& Topić (2005). The legal protection status in Croatia is in accordance with the Ordinance on strictly protected species (NN 144/13, 73/16), and is marked by an asterisk $\left(^{*}\right)$. 
Indicators of anthropogenic changes in the researched flora were calculated and determined according to ЈАскошіак $(1990,2006)$ as follows:

1. Indicators of anthropisation: 1.1. IAn $\mathrm{IA}_{\mathrm{t}}$-indicator of total anthropisation, $\mathrm{IAn}_{\mathrm{t}}=$ $(\mathrm{An} /(\mathrm{Sp}+\mathrm{An})) * 100,1.2$. $\mathrm{IAn}_{\mathrm{p}}$ - indicator of permanent anthropisation, $\mathrm{IAn}_{\mathrm{p}}=$ $(\mathrm{Mt} /(\mathrm{Sp}+\mathrm{Mt}) * 100)$;

2. Indicators of archeophytisation: 2.1 $\mathrm{IAr}_{\mathrm{t}}$ - indicator of total archeophytisation, $\mathrm{IAr}_{\mathrm{t}}$ $=(\mathrm{Ar} /(\mathrm{Sp}+\mathrm{An}) * 100$;

2.2 $\mathrm{IAr}_{\mathrm{p}-}$ indicator of permanent archeophytisation, $\operatorname{IAr}_{\mathrm{p}}=(\mathrm{Ar} /(\mathrm{Sp}+\mathrm{Mt}) * 100$;

3. Indicators of kenophytisation: $3.1 \mathrm{IK}_{\mathrm{t}}$ - indicator of total kenophytisation, $\mathrm{IK} \mathrm{n}_{\mathrm{t}}$ $=\left(\mathrm{Kn} /(\mathrm{Sp}+\mathrm{An})^{*} 100,3.2 \mathrm{IKn}_{\mathrm{p}}\right.$ - indicator of permanent kenophytisation, $\mathrm{IKn}_{\mathrm{p}}=$ $(\mathrm{Kn} /(\mathrm{Sp}+\mathrm{Mt}) * 100$

4. IM - indicator of modernisation, $\mathrm{IM}=(\mathrm{Kn} / \mathrm{Mt}) * 100$;

5. IF - indicator of fluctuation change; IF $=(\mathrm{Df} /(\mathrm{Sp}+\mathrm{An})$, (An represents the number of alien taxa, i.e. An = Ar + Kn + Df; Mt is the number of metaphytes - populations of permanently present alien taxa on a specific area, i.e. $\mathrm{Mt}=\mathrm{Ar}+\mathrm{Kn}$ ).

For comparative analysis with other areas the indicator values of anthropogenic changes for Savica were taken from Alegro et al. (2013), and for Jarun were calculated from Vuković et al. (2013).

\section{RESULTS}

In the researched area a total of 389 vascular plant taxa were observed, and classified into 77 families (Appendix 1). The taxonomic analysis showed that the phylum Monilophyta (Pteridophyta) is represented by nine species that belong to five families $(2.3 \%)$. The phylum Spermatophyta is represented by 381 taxa, which belong to 72 families (97.7\%). Among them only four taxa (within two families) belong to the Gymnospermae $(1.0 \%)$. Within the Angiospermae both ANITA and Magnolianae are represented with one taxon each $(0.3 \%)$. Furthermore, the monocots (Lilianae) are represented by 62 taxa within nine families (15.9\%), and the dicots (Eudicotyledones) with 312 taxa within 59 families $(80.2 \%)$.

The most common plant families are (Appendix 1) Fabaceae (36 taxa), Poaceae (30 taxa) Asteraceae (29 taxa), Lamiaceae (24 taxa) and Rosaceae (20 taxa). Since a large

Tab. 1. Comparison of indicators of anthropogenic changes in the flora of the investigated area of Hrvatsko zagorje with the flora of Jarun (Vuković et al., 2013) and Savica (Alegro et al., 2013), (abbreviations are explained in the chapter Methods).

\begin{tabular}{|l|c|c|c|}
\hline Indicators of anthropogenic changes & $\begin{array}{c}\text { Researched area } \\
\text { (Hrv. zagorje) }\end{array}$ & Jarun & Savica \\
\hline Indicator of total anthropisation $\left(\mathrm{IAn}_{\mathrm{t}}\right)$ & $\mathbf{1 6 . 4 5}$ & 25.38 & 27.78 \\
\hline Indicator of permanent anthropisation $\left(\mathrm{IAn}_{\mathrm{p}}\right)$ & $\mathbf{1 4 . 9 2}$ & 24.21 & 26.76 \\
\hline Indicator of total archeophytisation $\left(\mathrm{IAr}_{\mathrm{t}}\right)$ & $\mathbf{1 0 . 0 3}$ & 13.93 & 16.67 \\
\hline Indicator of permanent archeophytisation $\left(\mathrm{IAr}_{\mathrm{p}}\right)$ & $\mathbf{1 0 . 2 1}$ & 14.15 & 16.90 \\
\hline Indicator of total kenophytisation $\left(\mathrm{IKn}_{\mathrm{t}}\right)$ & $\mathbf{4 . 6 3}$ & 9.91 & 9.72 \\
\hline Indicator of permanent kenophytisation $\left(\mathrm{IKn}_{\mathrm{p}}\right)$ & $\mathbf{4 . 7 1}$ & 10.06 & 9.86 \\
\hline Indicator of modernisation $(\mathrm{IM})$ & $\mathbf{3 1 . 5 8}$ & 41.56 & 36.84 \\
\hline Indicator of fluctuation change $(\mathrm{IF})$ & $\mathbf{1 . 8 0}$ & 1.55 & 1.39 \\
\hline
\end{tabular}



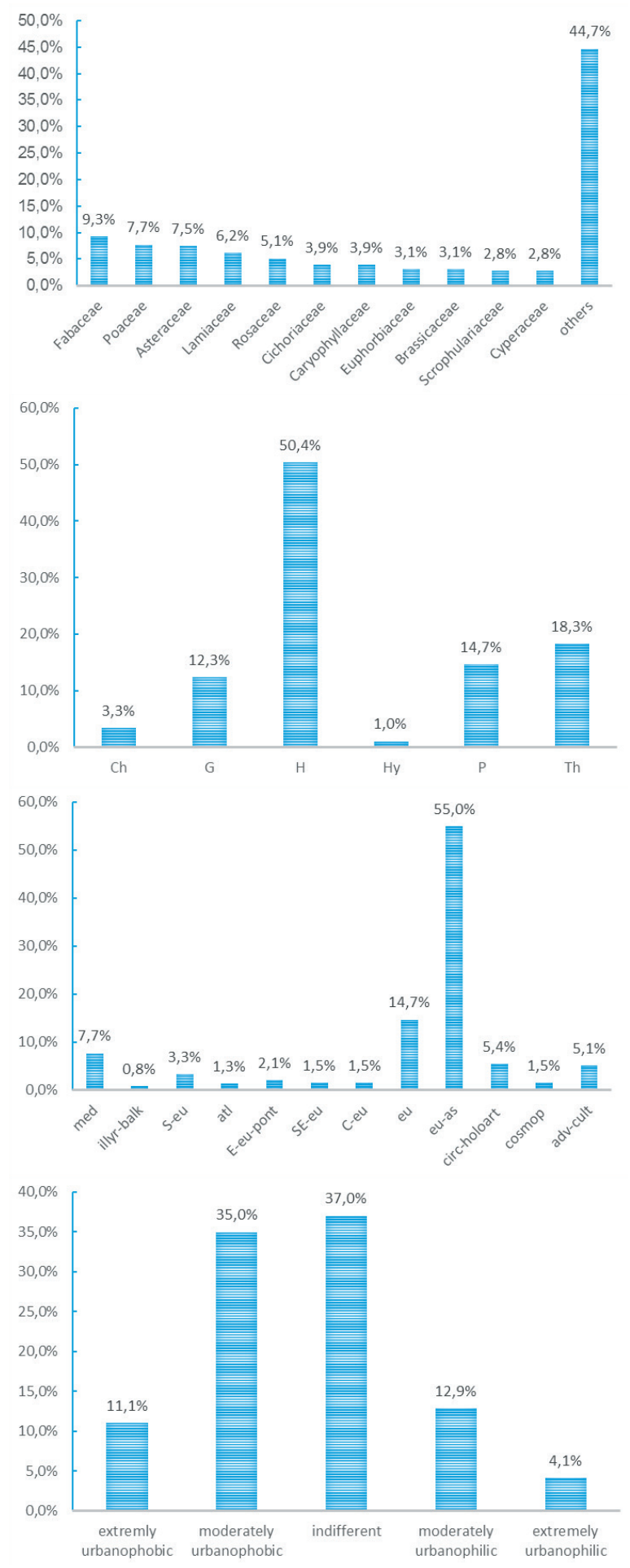

Fig. 2. The most common families in the investigated area of Hrvatsko zagorje.

Fig. 3. The share of life forms in the investigated area of Hrvatsko zagorje (abbreviations are explained in the chapter Methods).

Fig. 4. The share of chorological types in the investigated area of Hrvatsko zagorje (abbreviations are explained in the chapter Methods).

Fig. 5. The share of urbanophobic, indifferent and urbanophilic plants in the investigated area of Hrvatsko zagorje. 
number of families have been reported, of which 29 are represented by only one taxon, only families with more than 10 taxa were taken for a more transparent graphical representation, and all other families were classified as "others" (Fig. 2).

The analysis of life forms (App. 1, Fig. 3) showed that the most common were hemicryptophytes (196 taxa), followed by therophytes (71 taxa), phanerophytes (57 taxa), geophytes (48 taxa), chamaephytes (13 taxa) and only four hydrophytes.

Chorological analysis (App. 1, Fig. 4) points to the absolute dominance of the Eurasian chorological type (214 taxa), followed by European (57 taxa), Mediterranean (30 taxa), circumholarctic (21 taxa), and the adventive and cultivated chorological type (20 taxa). Least represented is the Illyrian-Balkan chorological type (only three plants).

Considering the tolerance of plants to anthropogenic influence in the research area, the most numerous are indifferent plants (37.0\%). Furthermore, the moderately urbanophobic and extremely urbanophobic plants are significantly more numerous than moderately urbanophilic and extremely urbanophilic (App. 1, Fig. 5).

Native taxa make up the majority of flora $(83.3 \%)$ of the exploration area. Archaeophytes prevail among alien plants (39 taxa), followed by kenophytes (neophytes, 18 taxa) and diaphytes (7 taxa) (App. 1). Eleven plants (2.8\%) represent invasive alien taxa.

Only one species, Cardamine waldsteinii Dyer, was recorded as endemic taxon. Glyceria plicata (Fr.) Fr. is the only species found in one of the high-risk IUCN categories (vulnerable taxa, VU). Eight taxa are strictly protected (App. 1).

Analysis of indicators of anthropogenic changes (Tab. 1) showed small differences between the total and the permanent values of the investigated indicators of anthropogenic changes, as well as the low value of the indicator of fluctuating changes, which indicate that the existing populations have usually established permanent populations. It also showed that the researched flora is more affected by archaeophytes than by kenophytes, for although the indicator of modernization is relatively high $(31.58 \%)$, it refers to a relatively small number of kenophytes (18 taxa), and larger number of established archaeophytes (39 taxa).

\section{DISCUSSION}

In all, 389 vascular flora species, classified into 77 families, were recorded over an area of about four $\mathrm{km}^{2}$. There are 34 geocoded sites associated with the listed species, which are a good basis for both understanding the present floristic diversity and monitoring future vascular flora changes in the area of the planned Regional Park. The relatively large floristic diversity of the explored area is probably the result of heterogeneous habitats (forest areas, grasslands, ponds, cultivated and inhabited areas). However, extreme weather conditions (high temperatures and pronounced drought during the vegetation season of 2011), as well as the practice of burning off fields by the local population, may have contributed to the 'invisibility' of some species, especially annuals. In that sense, floristic research over a longer period of time would certainly contribute to a more valuable evaluation of the floristic diversity of the exploration area and the whole area of the planned Hrvatsko zagorje Regional Park.

The most common plant families in our research are Fabaceae, Poaceae, Asteraceae, Lamiaceae and Rosaceae. If we incorporate the families Asteraceae and Cichoriaceae within the unique Compositae family, as is commonly done, then this is the most common family (44 taxa) in the investigated area. This kind of pattern layout of plant 
families is expected for the territory of the Republic of Croatia (Nikolić \& TopIć, 2005), with the exception of the Lamiaceae and Rosaceae families that are richer with species in our research than on the national level. Nevertheless, floristic researche in the continental biogeographical region regularly classifies the Lamiaceae and Rosaceae families within the five richest families, in terms of species number (e.g. Miтić et al., 2007; HruŠEvar, 2009; Hudina et al., 2012). Different types of Lamiaceae taxa occupy different ecological niches, and heterogeneous habitats obviously increase their share. On the other hand, the increased presence of the Rosaceae family is partially related to humankind, because some of them probably often escape from cultivation, e.g. Malus pumila, Prunus cerasifera, Prunus domestica, etc.

The analysis of life forms shows the absolute dominance of hemicryptophytes $(50.4 \%)$, which is to be expected for an area with a moderate climate (HoRvAT, 1949). Therophytes are the second most common form of life, and their share of $18.3 \%$ tends to suggest a low to moderate intensity of anthropogenic pressure. Namely, a large number of alien species survive unfavourable conditions in the form of seeds (e.g. SiLva \& SMITH, 2005; Medvecké et al., 2012; PYŠEK et al., 2012). An increase in the share of this life form indicates anthropogenic pressure (PiLková, 2015), which has been used as an indicator of human influence on the flora of Central Europe since the end of the 20th century (SuKopp \& Werner, 1983; Sudnik-Wojcikowska, 1988; Pyšek \& PyšEK, 1990, 1991). Compared with the flora of (sub)urban areas of the continental biogeographical region of Croatia (Hudina et al., 2012; Alegro et al., 2013; Vuković et al., 2013), the flora of the investigated area shows a smaller share of taxa of this life form and thus indirectly points to a better preservation of habitats. Even more in favour of this are the shares of urbanophobic vs. urbanophilic taxa (46.0\% vs. 17.0\%). Although Landolt's indicator (LANDOLT et al., 2010) referring to the 'naturalness' or 'artificiality' of plant cover, has not been used in past floristic research in Croatia, we consider it a good indicator of anthropogenic influence and in our research its indicative value points to weak anthropogenic pressure. Since the research area is sparsely inhabited (small villages with typical old houses and gardens and numerous cottages that are not permanently inhabited) the anthropogenic pressure, although present, is significantly alleviated.

Although there are no standardised criteria in chorological type assessment, we adopted the more recent approach of Alegro et al. (2013), Vuković et al. (2013) and Budisavljević et al. (2017), based on LANDOLT et al. (2010). Consequently, the chorological types from our research are not comparable to older works (before 2010), and are partly comparable with the results from the analysis of chorological type of Dotršćina (due to the homogeneity of the habitat; BudisAvljević et al., 2017), as well as those of Jarun (due to the anthropogenic influences; Vuković et al., 2013). The most relevant is the comparison of our investigated area with Savica (Alegro et al., 2013). Differences in the proportions of the chorological types arise, as previously pointed out by Vuković et al. (2013), from the fact that a large number of species considered cosmopolitan in earlier works are now referred to as Eurasian or Mediterranean. In this respect, the share of the Euro-Asian chorological type of $55.0 \%$ in our research is not surprising, and is not significantly higher than the foreseen share for Savica - 48.3\%, although it differs somewhat from data for Dotršćina and Jarun (44.1\%) (BuDisAvLJEvić et al., 2017). In support of the fact of nature preservation in the area of the planned Regional Park, the share of adventive and cultivated plants $(5.1 \%)$ is also very important, for it is twice as low as that of Savica (Alegro et al., 2013), almost twice as low as Jarun (Vuković et al., 2013) and somewhat lower than Dotršćina (Budisavljević et al., 2017). Similar results were noted for the Mediterranean chorological 
type, which encompasses a large number of pioneering or weed species, whose share in the researched area of the planned Regional Park is several percent lower than at Dotršćina, Jarun or Savica. The Illyrian-Balkan chorological type is represented by only three species: Cardamine waldsteinii, Euphorbia carniolica and Lamium orvala; this chorological type is strictly related to climate-zonal forest vegetation (ALEGro et al., 2006), so a small number of species could be explained by the fragmentation of the habitat and probably by the secondary character of a part of the forest stands. Plants of the Atlantic chorological type are rare in the flora of Croatia (Nikolić \& Topić, 2005), and therefore their low share in our research is expected. The analysis of alien flora indicates the domination of archaeophyta, most of them representing weed and ruderal species (e.g. Anagallis arvensis, Capsella bursa-pastoris, Convolvulus arvensis, Cichorium intybus, Sonchus asper etc.), while some also belong to the azonal forest vegetation, for example Castanea sativa in acidic soils. Frequent diaphytes in the investigated area are Juglans regia and Helianthus annua that easily escape from cultivation, but in the researched area, they do not form (self) sustainable populations. Although the new taxa are not always competitive enough in the continental biogeographical region, the Mediterranean chorological type is increasingly more observed (HrušEvar et al., 2014), probably due to the already mentioned modern approach to chorological analysis, and partly due to frequent planting and breeding of plants originating from the Mediterranean, as well (Šiljković \& RimANić, 2005; POHAJDA, 2014; Đurić, 2016). Specifically, the Mediterranean plants are distinguished by a higher proportion of alien species in the investigated area, with the share of $36.7 \%$ of archaeophytes, $10.0 \%$ of kenophytes (neophytes) and $6.7 \%$ of diaphytes. Most of the neophytes are simultaneously invasive taxa, originating mainly from North America and according to lifeform type are therophytes. Of the total of 38 invasive taxa recorded for the area of Hrvatsko Zagorje (VeIć, 2015), a relatively low amount of invasive plants (11 taxa; three invasive taxa per $\mathrm{km}^{2}$ ) in our research reflects a relatively good ecological balance and weak or moderate anthropogenic pressure on the area proposed for the future Regional Park.

On the investigated area, only the Glyceria plicata belongs to one of the IUCN threatened categories, being classified as vulnerable (VU), while SALkić (2012) recorded two more taxa within the same category (VU) - Carex panicea L. and Platanthera bifolia (L.) Rich. in the nearby area, which should also be included in the planned Regional Park. The new legislation (ANONYMous, 2013, 2016) significantly altered the list of protected species and it is impossible to compare our data with the results of older floristic researches. We found eight strictly protected plants, including the only recorded endemic species - Cardamine waldsteinii. Since the centres of endemism for the territory of the Republic of Croatia are located in the Mediterranean and Alpine biogeographical regions (NiкоLıć et al., 2015), a larger number of endemic taxa were not expected to be observed at the researched area. Indices of anthropisation for the area of the planned Regional Park show a value of ten units lower than the value for Zagreb settlements (Tab. 1), undoubtedly confirming the (semi)natural character of the investigated area. Large differences in archaeophytic and kenophytic indices arise from significant differences in the constituents of the chronoelement of the established alien taxa, while the slight differences between the total and permanent values of the index are the result of the low proportion of diaphytes. The modernization index (IM) is also lower than for Savica and Jarun, but the fluctuation index (IF) is somewhat higher, due to the smaller number of diaphytes in the total number of species. 
To conclude, our floristic research shows the semi-natural character of the investigated part of the planned Regional Park, which is under weak to moderate anthropogenic pressure. Although the share of endangered, protected and endemic plant species is low, the diversity of other native plants of the area, as well as small number of alien plants, justify planning the protection of this part of the Hrvatsko zagorje at the level of a regional park.

\section{ACKNOWLEDGEMENT}

We would like to thank the State Institute for Nature Protection (today Croatian Environment and Nature Agency) which enabled us the fieldwork. Special thanks go to their employees Vida Posavec Vukelić and Igor Boršić, who initiated this research and to I. Boršić for providing us the map of the researched area. Additionally, we would like to thank the referees for their valuable remarks.

Received November 10, 2018

\section{REFERENCES}

Alegro, A. \& Bogdanović, S., 2003: Ključevi za određivanje svojti kritičnih skupina. Botanički zavod PMF-a. InternaL version br. 01. (In Croatian)

Alegro, A., Marković, Lj., Antonić, O. \& Bogdanović, S., 2006: Historical and functional aspects of plant biodiversity - an example on the flora of the Vukova Gorica region (Central Croatia). Candollea 61(1), 135-166.

Alegro, A., Bogdanović, S., RešEtnik, I., Boršić, I., Cigić, P. \& Nikolić, T., 2013: Flora of the seminatural marshland Savica, part of the (sub)urban flora of the city of Zagreb (Croatia). Natura Croatica 22(1), 111-134.

AnONYmous, 2007: Strategija i akcijski plan zaštite biološke i krajobrazne raznolikosti Republike Hrvatske. Narodne novine, 143/2008. (In Croatian)

Anonymous, 2008: Statistički ljetopis. Državni zavod za statistiku, Zagreb. (In Croatian)

Anonymous, 2013: Pravilnik o strogo zaštićenim vrstama. Narodne novine, 144/2013. (In Croatian)

AnONYmous, 2014: Agencija za plaćanja u poljoprivredi, ribarstvu i ruralnom razvoju - ARKOD preglednik. http://preglednik.arkod.hr/ARKOD-Web/, pristupljeno 03.05.2014. (In Croatian)

Anonymous, 2016: Pravilnik o izmjenama i dopunama Pravilnika o strogo zaštićenim vrstama. Narodne novine, 73/2016. (In Croatian)

BorovečKI-Voska, Lj., 2010: Orhideje na Strahinjščici i susjednim područjima. Alfa, Zagreb. (In Croatian)

Boršić, I., Milović, M., Dujmović, I., Bogdanović, S., Cigić, P., RešEtnik, I., Nikolić, T. \& Mitić, B., 2008 : Preliminary check-list of invasive alien plant species (IAS) in Croatia. Natura Croatica 17(2), 55-71.

Budisavljević, A., Terlević, A., Mihelić, P., Špadina, B., Papković, D., Nikolić, T. \& ŠEgota, V., 2017: Vaskularna flora šume Dotrščina (Zagreb, Hrvatska). Glasnik Hrvatskog Botaničkog Društva 5(1), 4-19. (In Croatian)

ČAPlAR, A., 2011: Planinarski vodič po Hrvatskoj. Mozaik knjiga, Zagreb. (In Croatian)

Domac, R., 2002: Flora Hrvatske - Priručnik za određivanje bilja. Školska knjiga, Zagreb. (In Croatian)

ĐuRIć, B., 2016: Eco food tura - analiza stanja i mogućnosti razvoja ekološke proizvodnje s posebnim osvrtom na MAP sektor uključujući akcijski plan. Udruga poduzetnika i poslodavaca Žepče i Lokalna agencija za razvoj Vjeverica d.o.o. Drenovci, Županja. (In Croatian)

FıLıPčıć, A., 1998: Klimatska regionalizacija Hrvatske po Köppenu za standardno razdoblje 1961.-1990. u odnosu na razdoblje 1931.-1960., Acta Geographica Croatica 34, 1-15. (In Croatian)

Hirc, D., 1917: Florističke studije po Hrvatskom zagorju. Prirodoslovna istraživanja Jugoslavenske Akademije znanosti i umjetnosti 11/12, 62-116. (In Croatian)

Horvat, I., 1929: Rasprostranjenje i prošlost mediteranskih, ilirskih i pontskih elemenata u flori sjeverne Hrvatske i Slovenije. Acta Botanica Croatica 4(1), 1-34. (In Croatian)

Horvat, I., 1949: Nauka o biljnim zajednicama. Nakladni zavod Hrvatske, Zagreb. (In Croatian)

Horvat, M., 2017: Flora uz antropogene vodene površine ludbreškog kraja. Diplomski rad, Sveučilište u Zagrebu, Prirodoslovno-matematički fakultet, Biološki odsjek, Zagreb. (In Croatian) 
HoRvatić, S., 1931: Bilješke o nekim manje poznatim biljkama iz hrvatske flore. Acta Botanica Croatica 6(1), 56-65. (In Croatian)

Horvatić, S., 1963: Vegetacijska karta otoka Paga s općim pregledom vegetacijskih jedinica hrvatskog primorja. Prirodoslovna istraživanja serija Acta Biologica 4(33), 5-181. (In Croatian)

Horvatić, S., Ilijanić, Lj. \& Marković-Gospodarić, Lj., 1967-1968: Biljni pokrov okoline Senja. Senjski zbornik 3, 298-323. (In Croatian)

HrušEvar, D., 2009: Flora istočne Medvednice. Diplomski rad, Sveučilište u Zagrebu, Prirodoslovno-matematički fakultet, Biološki odsjek, Zagreb. (In Croatian)

Hruševar, D., Mitić, B., Sandev, D. \& Alegro, A., 2014: New records of vascular plants on the Mt Medvednica. Natura Croatica 23(2), 275-286.

Hubbard, C. E., 1992: Grasses - A Guide to their Structure, Identification, Uses and Distribution in the British Isles. Penguin books, London.

Hudina, T., Salkić, B., Rimac, A., Bogdanović, S. \& Nikolić, T., 2012: Contribution to the urban flora of Zagreb (Croatia): Natura Croatica 21(2), 357-372.

JaскошіAK, B., 1990: Antropogeniczne przemiany flory roślin naczyniowych Poznania. Wyd. Naukowe Uniwersytety A. Mickiewicza w Poznaniu, ser. Biol. 42, 1-208.

JAСКошіАK, B., 2006: Methodological proposals for studies on the structure and dynamics of urban flora. Pol. Bot. Stud. 22, 251-260.

Jávorka, S. \& CsApody, V., 1991: Iconographia florae partis Austro-orientalis Europae centralis. Akadémiai Kiadó, Budapest.

Jermy, A. C. \& Tutin, T. G., 1982: Sedges of the British Isles. Botanical Society of the British Isles, London.

Kornaś, J., 1981: Oddziaływanie człowieka na florę: mechanizmy i konsekwencje. Wiad. Bot. 25, 165-182.

Landolt, E., Bäumler, B., Erhardt, A., Hegg, O., Klötzli, F., Lämmler, W., Nobis, M., Rudmann-Maurer, K., Schweingruber, F. H., Theurillat, J-P., Urmi, E., Vust, M. \& Wohlgemuth, T., 2010: Flora indicativa. Ökologische Zeigerwerte und biologische Kennzeichen zur Flora der Schweiz und der Alpen. Editions des Conservatoire et Jardin botaniques de la Ville de Genève \& Haupt Verlag, BernStuttgart-Wien.

Martinčić, A., Wraber, T., Jogan, N., Ravnik, V., Podobnik, A., Turk, B. \& Vreš, B., 1999: Mala flora Slovenije - ključ za določanje paprotnic in semenk. Tehniška založba Slovenije, Ljubljana. (In Slovenian)

Medvecká, J., Kliment, J., Májeková, J., Halada, L'., Zaliberová, M., Gojdičová, E., Feráková, V. \& JARoLÍmeK, I., 2012: Inventory of the alien flora of Slovakia. Preslia 84, 257-309.

Mirek, Z., 1981: Problemy klasifikacji roślin synantropijnych. Wiad. Bot. 25, 45-54.

Mitić, B., Kajfež, A., Cigić, P. \& ReŠEtnik, I., 2007: The flora of Stupnik and its surroudings (Northwest Croatia). Natura Croatica 16(2), 147-169.

Mitić, B., Boršıć, I., Dujmović, I., Bogdanović, S., Milović, M., Cigić, P., RešEtnik, I. \& Nikolić, T., 2008 : Alien flora of Croatia: proposal for standards in terminology, criteria and related databse. Natura Croatica 17(2), 73-90.

Niкоцı́́, T., 2013: Sistematska botanika - raznolikost i evolucija biljnog svijeta. Alfa, Zagreb. (In Croatian)

Nikolić, T., 2018: Flora Croatica Database. On-Line (http://hirc.botanic.hr/fcd). Botanički zavod, Prirodoslovno-matematički fakultet, Sveučilište u Zagrebu. Accessed on July $15^{\text {th }} 2018$.

Nikolić, T., Milović, M., Bogdanović, S. \& Jasprica, N., 2015: Endemi u hrvatskoj flori. Alfa, Zagreb. (In Croatian)

Nikolić, T. \& Topić, J., 2005: Crvena knjiga vaskularne flore Hrvatske. Ministarstvo kulture Republike Hrvatske, Državni zavod za zaštitu prirode, Zagreb. (In Croatian)

Pilková, I., 2015: Species structure of plants in the Báb forest after logging. Ekológia (Bratislava), 34(4), 293-308.

Pohajda, I., 2014: Ljekovito i aromatično bilje - Lavanda. Treće izmijenjeno i dopunjeno izdanje. Hrvatska poljoprivredno - šumarska savjetodavna služba, Zagreb. (In Croatian)

PolJAK, Ž., 2007: Hrvatske planine. Planinarsko turistički vodič s atlasom. Golden marketing-Tehnička knjiga, Zagreb. (In Croatian)

Pyšek, P., Danihelk, J., Sádlo, J., Chrtek, J. Jr., Chytrý, M., Jarošík, V., Kaplan, Z., Krahulec, F., Moravcová, L., Pergl, J., Štajerová, K. \& TichÝ, L., 2012: Catalogue of alien plants of the Czech Republic (2nd edition). Preslia 84, 155-255. 
PYšEK, P. \& PYšEK, A., 1990: Comparision of the vegetation and flora of the West Bohemian villages and towns. In: Sukopp, H., Hejny, S., Kowarik, I. (eds.), Urban Ecology. Plants and plant communities in urban environments. SPB Academic Publishing, The Hague, p. 105-112.

PYšEK, P. \& PYšEK, A., 1991: Vergleich der dörflichen und staädtischen Ruderalflora, dargestellt am Beispiel Westböhmens. Tuexenia 11, 121-134.

Regula-Bevilacqua, LJ., 1978: Biljni pokrov Strahinščice u Hrvatskom zagorju. Doktorska disertacija, Sveučilište u Zagrebu, Prirodoslovno-matematički fakultet, Biološki odsjek, Zagreb. (In Croatian)

Regula-Bevilacqua, Lj., 1985: Kritički osvrt na neke podatke o flori Hrvatskog zagorja. Acta Botanica Croatica 44(1), 91-98. (In Croatian)

Regula-Bevilacqua, Lj., 1986: Neke rijetke i zanimljive vrste u flori Strahinščice. Acta Botanica Croatica 45(1), 91-98. (In Croatian)

Regula-Bevilacqua, Lj., 1991: Beitrag zur Flora des Gebietes von Krapina, Radoboj und des Gebirgszuges Strahinščica in Hrvatsko zagorje. Acta Botanica Croatica 50(1),115-127.

Regula-Bevilacqua, Lj. \& Šegulja, N., 2000: Analyse der Flora des Gebirgszuges Strahinščica im Hrvatsko zagorje (Kroatien). Acta Botanica Croatica 59(1), 243-278.

Rothmaler, W. \& JäGER, E. J., 2007: Exkursionsflora von Deutschland, Band 3-Gefäßpflanzen: Atlasband. Elsevier Spektrum Akademischer Verlag, Heidelberg-Berlin.

SALKIĆ, B., 2012: Flora planiranog Regionalnog parka Hrvatsko zagorje - okolica sela Gornje i Donje Jesenje. Diplomski rad, Sveučilište u Zagrebu, Prirodoslovno-matematički fakultet, Biološki odsjek, Zagreb. (In Croatian)

StANČić, Z., 1994: Prikaz i analiza flore okolice Konjšćine (Hrvatska). Acta Botanica Croatica 53(1), 125140. (In Croatian)

STANČIĆ, Z. (2000): Travnjaci razreda Molinio-Arrhenatheretea u sjeverozapadnoj Hrvatskoj. Doktorska disertacija, Sveučilište u Zagrebu, Prirodoslovno-matematički fakultet, Biološki odsjek, Zagreb. (In Croatian)

Silva, L. \& Sмiтh, C. W., 2005: A quantitative approach to the study of non-indigenous plants: an example from the Azores Archipelago. Biodiversity \& Conservation 15(5), 1661-1679.

SudNik-WојсікоwsкA, B., 1988: Flora synanthropization and anthropopressure zones in a large urban agglomeration (exemplified by Warsaw). Flora 180, 259-265.

SuKopP, H. \& Werner, P., 1983: Urban environments and vegetation. In: Holzner, W., Werger, M. J. A., Iкusima, I. (eds.): Man's impact on vegetation. Kluwer, Boston, p. 247-260.

Šıljković, Ž. \& Rimanić, A., 2005: Geographic Aspects of Medicinal Plants Organic Growing in Croatia. Geoadria 10, 53-68.

ŠINCEK, D., 2003: Biljni svijet Ivančice i Ravne gore. Biblioteka “Ravna gora”, Knjiga 10. Vall 042 \& Planinarsko društvo "Ravna gora", Varaždin. (In Croatian)

ŠINCEK, D., Remar Ž. \& BoroveČKI-VosKa, LJ., 2012: Praćenje populacija i kartiranje staništa biljnih svojti: alpski jaglac (Primula auricula), kranjski ljiljan (Lilium carniolicum), lukovičavi ljiljan (Lilium bulbiferum), crveni likovac (Daphne cneorum), mirisni vranjak (Gymnadenia odoratissima) i crvena vratiželja (Anacamptis pyramidalis) i tisa (Taxus baccata) na području Ivanščice u Varaždinskoj županiji. Javna ustanova "PRIRODA Varaždinske županije" (https://priroda-vz.hr/istrazivanja/). (In Croatian)

ŠEGOTA, T. \& FiLIPČIć, A., 2003: Köppenova podjela klima i hrvatsko nazivlje. Geoadria, 8/1, 17-37. (In Croatian)

Šoštarić, R. \& Marković, LJ., 1998: The flora of Krapinske Toplice (Croatia). Acta Botanica Croatica 55/56(1), 101-118.

Tutin, T. G., Burges, N. A., Chater, A.O., Edmondson, J. R., Heywood, W. H., Moore, D. M., Valentine, D. H., Walters, S. M. \& Weвb, D. A., 1993: Flora Europaea vol. 1, $2^{\text {nd }}$ ed. Cambridge University Press, Cambridge.

Tutin, T. G., Heywood, V. H., Burges, N. A., Moore, D. M., Valentine, D. H., Walters, S. M. \& Webb, D. A., 1968-1980: Flora Europaea vol. 2-5. Cambridge University Press, Cambridge.

VeIć, A. M., 2015: Invazivna flora u Hrvatskom zagorju. Diplomski rad, Međimursko veleučilište u Čakovcu, Održivi razvoj, Čakovec. (In Croatian)

Vuković, N., Boršić, I., Župan, D., Alegro, A. \& Nikolić, T., 2013: Vascular flora of Jarun (Zagreb, Croatia). Natura Croatica 22(2), 275-294. 
Appendix 1. Vascular flora of the researched part of the planned Regional park "Hrvatsko zagorje“ (CHOROTYPE - chorological type; URB INFL- indicators of anthropogenic influence on plants (urbanophobia / indifference / urbanophilia); GEO ORIGIN - geographical origin; END / TH / PROTECT endemic / threatened / protected taxa; other abbreviations and marks are explained in the chapter Methods).

\begin{tabular}{|c|c|c|c|c|c|c|c|}
\hline Family & Taxon & $\begin{array}{c}\text { LIFE } \\
\text { FORM }\end{array}$ & $\begin{array}{l}\text { CHORO- } \\
\text { TYPE }\end{array}$ & $\begin{array}{l}\text { URB } \\
\text { INFL }\end{array}$ & ORIGIN & $\begin{array}{c}\text { GEO } \\
\text { ORIGIN }\end{array}$ & $\begin{array}{l}\text { END / TH / } \\
\text { PROTECT }\end{array}$ \\
\hline \multicolumn{8}{|c|}{ MONILOPHYTA (PTERIDOPHYTA) } \\
\hline Dryopteridaceae & $\begin{array}{l}\text { Dryopteris carthusiana (Vill.) H. } \\
\text { P. Fuchs }\end{array}$ & $\mathrm{H}$ & 11 & 1 & $\mathrm{sp}$ & & \\
\hline Dryopteridaceae & Dryopteris filix-mas (L.) Schott & G & 10 & 3 & $\mathrm{sp}$ & & \\
\hline Equisetaceae & Equisetum arvense $\mathrm{L}$. & G & 10 & 3 & $\mathrm{sp}$ & & \\
\hline Equisetaceae & Equisetum palustre $\mathrm{L}$. & G & 10 & 2 & $\mathrm{sp}$ & & \\
\hline Equisetaceae & Equisetum pratense Ehrh. & G & 10 & 2 & $\mathrm{sp}$ & & \\
\hline Equisetaceae & Equisetum telmateia Ehrh. & G & 10 & 2 & $\mathrm{sp}$ & & \\
\hline Hypolepidaceae & Pteridium aquilinum (L.) Kuhn & G & 11 & 2 & $\mathrm{sp}$ & & \\
\hline Polypodiaceae & Polypodium vulgare L. & $\mathrm{H}$ & 9 & 1 & $\mathrm{sp}$ & & \\
\hline Woodsiaceae & Athyrium filix-femina (L.) Roth & $\mathrm{H}$ & 9 & 1 & $\mathrm{sp}$ & & \\
\hline \multicolumn{8}{|c|}{ SPERMATOPHYTA - GYMNOSPERMAE } \\
\hline Cupressaceae & Juniperus communis L. & $\mathrm{P}$ & 9 & 2 & $\mathrm{sp}$ & & \\
\hline Pinaceae & Abies alba Mill. & $\mathrm{P}$ & 7 & 2 & sp & & \\
\hline Pinaceae & Picea abies (L.) Karsten & $\mathrm{P}$ & 8 & 2 & $\mathrm{sp}$ & & \\
\hline Pinaceae & Pinus sylvestris L. & $\mathrm{P}$ & 10 & 1 & $\mathrm{sp}$ & & \\
\hline \multicolumn{8}{|c|}{ SPERMATOPHYTA - ANGIOSPERMAE } \\
\hline \multicolumn{8}{|l|}{ ANITA } \\
\hline Nymphaeaceae & Nymphaea alba $\mathrm{L}$. & Hy & 8 & 2 & $\mathrm{sp}$ & & \\
\hline \multicolumn{8}{|l|}{ MAGNOLIANAE } \\
\hline Aristolochiaceae & Asarum europaeum $\mathrm{L}$. & $\mathrm{H}$ & 9 & 1 & $\mathrm{sp}$ & & \\
\hline \multicolumn{8}{|l|}{ LILIANAE } \\
\hline Cyperaceae & Carex acuta $\mathrm{L}$. & $\mathrm{H}$ & 9 & 2 & $\mathrm{sp}$ & & \\
\hline Cyperaceae & Carex caryophyllea Latourr. & G & 9 & 3 & $\mathrm{sp}$ & & \\
\hline Cyperaceae & Carex digitata $\mathrm{L}$. & $\mathrm{H}$ & 9 & 2 & $\mathrm{sp}$ & & \\
\hline Cyperaceae & Carex flacca Schreb. & G & 9 & 2 & $\mathrm{sp}$ & & \\
\hline Cyperaceae & Carex hirta $\mathrm{L}$. & G & 8 & 3 & $\mathrm{sp}$ & & \\
\hline Cyperaceae & Carex otrubae Podp. & $\mathrm{H}$ & 1 & 2 & $\mathrm{sp}$ & & \\
\hline Cyperaceae & Carex pallescens $\mathrm{L}$. & $\mathrm{H}$ & 9 & 2 & $\mathrm{sp}$ & & \\
\hline Cyperaceae & Carex spicata Huds. & $\mathrm{H}$ & 9 & 3 & $\mathrm{sp}$ & & \\
\hline Cyperaceae & Carex sylvatica Huds. & $\mathrm{H}$ & 9 & 3 & $\mathrm{sp}$ & & \\
\hline Cyperaceae & Carex vulpina L. & $\mathrm{H}$ & 9 & 2 & $\mathrm{sp}$ & & \\
\hline Cyperaceae & Scirpus sylvaticus L. & $G$ & 9 & 2 & $\mathrm{sp}$ & & \\
\hline Dioscoreaceae & Tamus communis $\mathrm{L}$. & G & 1 & 1 & $\mathrm{sp}$ & & \\
\hline Iridaceae & Iris pseudacorus L. & G & 9 & 2 & $\mathrm{sp}$ & & $*$ \\
\hline Juncaceae & Juncus compressus Jacq. & G & 9 & 2 & $\mathrm{sp}$ & & \\
\hline Juncaceae & Juncus effusus L. & $\mathrm{H}$ & 10 & 3 & $\mathrm{sp}$ & & \\
\hline Juncaceae & Juncus inflexus L. & $\mathrm{H}$ & 10 & 3 & $\mathrm{sp}$ & & \\
\hline Juncaceae & Luzula campestris (L.) DC. & $\mathrm{H}$ & 9 & 2 & $\mathrm{sp}$ & & \\
\hline Juncaceae & Luzula forsteri (Sm.) DC. & $\mathrm{H}$ & 1 & 2 & $\mathrm{sp}$ & & \\
\hline
\end{tabular}


Appendix 1. continued

\begin{tabular}{|c|c|c|c|c|c|c|c|}
\hline Family & Taxon & $\begin{array}{c}\text { LIFE } \\
\text { FORM }\end{array}$ & $\begin{array}{l}\text { CHORO- } \\
\text { TYPE }\end{array}$ & $\begin{array}{l}\text { URB } \\
\text { INFL }\end{array}$ & ORIGIN & $\begin{array}{c}\text { GEO } \\
\text { ORIGIN }\end{array}$ & $\begin{array}{l}\text { END / TH / } \\
\text { PROTECT }\end{array}$ \\
\hline Juncaceae & $\begin{array}{l}\text { Luzula luzuloides (Lam.) Dandy et } \\
\text { Wilmott }\end{array}$ & $\mathrm{H}$ & 8 & 1 & $\mathrm{sp}$ & & \\
\hline Juncaceae & Luzula multiflora (Retz.) Lej. & $\mathrm{H}$ & 10 & 2 & $\mathrm{sp}$ & & \\
\hline Juncaceae & Luzula pilosa (L.) Willd. & $\mathrm{H}$ & 9 & 1 & $\mathrm{sp}$ & & \\
\hline Liliaceae & Allium ursinum L. & G & 9 & 2 & $\mathrm{sp}$ & & \\
\hline Liliaceae & Convallaria majalis L. & G & 8 & 3 & $\mathrm{sp}$ & & \\
\hline Liliaceae & Ornithogalum pyramidale $\mathrm{L}$. & G & 1 & 3 & $\mathrm{sp}$ & & \\
\hline Liliaceae & $\begin{array}{l}\text { Ornithogalum sphaerocarpum A. } \\
\text { Kern. }\end{array}$ & G & 1 & 2 & $\mathrm{sp}$ & & \\
\hline Liliaceae & Ornithogalum umbellatum L. & G & 3 & 3 & $\mathrm{sp}$ & & \\
\hline Liliaceae & Polygonatum multiflorum (L.) All. & G & 9 & 1 & $\mathrm{sp}$ & & \\
\hline Orchidaceae & Cephalanthera longifolia (L.) Fritsch & G & 9 & 1 & $\mathrm{sp}$ & & * \\
\hline Orchidaceae & Neottia nidus-avis (L.) Rich. & G & 9 & 1 & $\mathrm{sp}$ & & * \\
\hline Poaceae & Agrostis capillaris L. & $\mathrm{H}$ & 9 & 2 & $\mathrm{sp}$ & & \\
\hline Poaceae & Agrostis stolonifera L. & $\mathrm{H}$ & 9 & 3 & $\mathrm{sp}$ & & \\
\hline Poaceae & Alopecurus pratensis L. & $\mathrm{H}$ & 9 & 3 & $\mathrm{sp}$ & & \\
\hline Poaceae & Anthoxanthum odoratum L. & $\mathrm{H}$ & 9 & 3 & $\mathrm{sp}$ & & \\
\hline Poaceae & $\begin{array}{l}\text { Arrhenatherum elatius (L.) J.Presl } \\
\text { et C.Presl }\end{array}$ & $\mathrm{H}$ & 9 & 4 & $\mathrm{sp}$ & & \\
\hline Poaceae & $\begin{array}{l}\text { Avenula pubescens (Dumort.) } \\
\text { Dumort. }\end{array}$ & $\mathrm{H}$ & 9 & 2 & $\mathrm{sp}$ & & \\
\hline Poaceae & $\begin{array}{l}\text { Brachypodium pinnatum (L.) } \\
\text { P.Beauv. ssp. pinnatum }\end{array}$ & $\mathrm{H}$ & 9 & 2 & ar & E & \\
\hline Poaceae & $\begin{array}{l}\text { Brachypodium sylvaticum (Huds.) } \\
\text { P.Beauv. }\end{array}$ & $\mathrm{H}$ & 9 & 3 & $\mathrm{sp}$ & & \\
\hline Poaceae & Briza media $\mathrm{L}$. & $\mathrm{H}$ & 9 & 2 & $\mathrm{sp}$ & & \\
\hline Poaceae & Bromus erectus Huds. & $\mathrm{H}$ & 9 & 2 & $\mathrm{sp}$ & & \\
\hline Poaceae & Bromus hordaceus L. & $\mathrm{T}$ & 9 & 4 & $\mathrm{sp}$ & & \\
\hline Poaceae & Bromus sterilis L. & $\mathrm{T}$ & 9 & 4 & ar & E As & \\
\hline Poaceae & Calamagrostis epigejos (L.) Roth & $\mathrm{H}$ & 9 & 3 & $\mathrm{sp}$ & & \\
\hline Poaceae & Dactylis glomerata $\mathrm{L}$. & $\mathrm{H}$ & 9 & 3 & $\mathrm{sp}$ & & \\
\hline Poaceae & Digitaria sanguinalis (L.) Scop. & $\mathrm{T}$ & 9 & 5 & ar & E As Af & \\
\hline Poaceae & Echinochloa crus-galli (L.) P.Beauv. & $\mathrm{T}$ & 12 & 5 & ar & E As & \\
\hline Poaceae & Festuca altissima All. & $\mathrm{H}$ & 9 & 1 & $\mathrm{sp}$ & & \\
\hline Poaceae & Festuca gigantea (L.) Vill. & $\mathrm{H}$ & 9 & 2 & $\mathrm{sp}$ & & \\
\hline Poaceae & Glyceria plicata (Fr.) Fr. & Hy & 9 & 2 & $\mathrm{sp}$ & & $\mathrm{VU}^{*}$ \\
\hline Poaceae & Holcus lanatus L. & $\mathrm{H}$ & 8 & 3 & $\mathrm{sp}$ & & \\
\hline Poaceae & Lolium multiflorum Lam. & $\mathrm{T}$ & 1 & 4 & $\mathrm{kn}$ & E As Af & \\
\hline Poaceae & Lolium perenne $\mathrm{L}$. & $\mathrm{H}$ & 9 & 3 & $\mathrm{sp}$ & & \\
\hline Poaceae & Phalaris arundinacea $\mathrm{L}$. & G & 11 & 2 & $\mathrm{sp}$ & & \\
\hline Poaceae & Phleum pratense $\mathrm{L}$. & $\mathrm{H}$ & 9 & 3 & $\mathrm{sp}$ & & \\
\hline Poaceae & $\begin{array}{l}\text { Phragmites australis (Cav.) Trin. } \\
\text { ex Steud. }\end{array}$ & G & 11 & 2 & $\mathrm{sp}$ & & \\
\hline Poaceae & Poa pratensis L. & $\mathrm{H}$ & 10 & 3 & $\mathrm{sp}$ & & \\
\hline Poaceae & Poa trivialis $\mathrm{L}$. & $\mathrm{H}$ & 10 & 3 & $\mathrm{sp}$ & & \\
\hline Poaceae & Setaria pumila (Poir.) Schult. & $\mathrm{T}$ & 12 & 4 & ar & E As & \\
\hline Poaceae & Trisetum flavescens (L.) P.Beauv. & $\mathrm{H}$ & 9 & 3 & $\mathrm{sp}$ & & \\
\hline Poaceae & Zea mays L. & $\mathrm{T}$ & 12 & 4 & $\mathrm{df}$ & CAm & \\
\hline
\end{tabular}


Appendix 1. continued

\begin{tabular}{|c|c|c|c|c|c|c|c|}
\hline Family & Taxon & $\begin{array}{c}\text { LIFE } \\
\text { FORM }\end{array}$ & $\begin{array}{l}\text { CHORO- } \\
\text { TYPE }\end{array}$ & $\begin{array}{l}\text { URB } \\
\text { INFL }\end{array}$ & ORIGIN & $\begin{array}{c}\text { GEO } \\
\text { ORIGIN }\end{array}$ & $\begin{array}{l}\text { END / TH / } \\
\text { PROTECT }\end{array}$ \\
\hline Potamogetonaceae & Potamogeton crispus L. & Hy & 9 & 2 & $\mathrm{sp}$ & & \\
\hline Potamogetonaceae & Potamogeton natans L. & Hy & 11 & 1 & $\mathrm{sp}$ & & \\
\hline Typhaceae & Typha latifolia L. & G & 10 & 2 & $\mathrm{sp}$ & & \\
\hline \multicolumn{8}{|c|}{ EUDICOTYLEDONES } \\
\hline Aceraceae & Acer campestre L. & $\mathrm{P}$ & 9 & 1 & $\mathrm{sp}$ & & \\
\hline Aceraceae & Acer platanoides L. & $\mathrm{P}$ & 8 & 3 & $\mathrm{sp}$ & & \\
\hline Aceraceae & Acer pseudolatanus L. & $\mathrm{P}$ & 7 & 3 & $\mathrm{sp}$ & & \\
\hline Amaranthaceae & Amaranthus hybridus L. & $\mathrm{T}$ & 12 & 5 & $\mathrm{kn}$ & NC Am & \\
\hline Apiaceae & Aegopodium podagraria $\mathrm{L}$. & G & 9 & 3 & $\mathrm{sp}$ & & \\
\hline Apiaceae & Angelica sylvestris L. & $\mathrm{H}$ & 9 & 2 & $\mathrm{sp}$ & & \\
\hline Apiaceae & Carum carvi $\mathrm{L}$. & $\mathrm{T}$ & 9 & 3 & $\mathrm{sp}$ & & \\
\hline Apiaceae & Chaerophyllum hirsutum L. & $\mathrm{H}$ & 7 & 2 & $\mathrm{sp}$ & & \\
\hline Apiaceae & Daucus carota $\mathrm{L}$. & $\mathrm{H}$ & 1 & 3 & $\mathrm{sp}$ & & \\
\hline Apiaceae & Foeniculum vulgare Mill. & $\mathrm{T}$ & 9 & 4 & $\mathrm{sp}$ & & \\
\hline Apiaceae & Heracleum sphondylium L. & $\mathrm{H}$ & 8 & 3 & $\mathrm{sp}$ & & \\
\hline Apiaceae & Pastinaca sativa $\mathrm{L}$. & $\mathrm{H}$ & 9 & 5 & $\mathrm{sp}$ & & \\
\hline Apiaceae & Torilis arvensis (Huds.) Link & $\mathrm{T}$ & 1 & 4 & ar & E & \\
\hline Apiaceae & Torilis japonica (Houtt.) DC. & $\mathrm{T}$ & 9 & 3 & $\mathrm{sp}$ & & \\
\hline Apocynaceae & Vinca minor L. & $\mathrm{Ch}$ & 9 & 3 & $\mathrm{sp}$ & & \\
\hline Araliaceae & Hedera helix $\mathrm{L}$. & $\mathrm{P}$ & 8 & 3 & $\mathrm{sp}$ & & \\
\hline Asclepiadaceae & Vincetoxicum hirundinaria Medik. & $\mathrm{H}$ & 9 & 2 & $\mathrm{sp}$ & & \\
\hline Asteraceae & Achillea millefolium $\mathrm{L}$. & $\mathrm{H}$ & 9 & 3 & $\mathrm{sp}$ & & \\
\hline Asteraceae & Ambrosia artemisiifolia $\mathrm{L}$. & $\mathrm{T}$ & 12 & 5 & kn (inv) & NAm & \\
\hline Asteraceae & Artemisia vulgaris L. & $\mathrm{H}$ & 9 & 4 & $\mathrm{sp}$ & & \\
\hline Asteraceae & Aster novi-belgii L. & $\mathrm{H}$ & 12 & 4 & $\mathrm{kn}$ & N Am & \\
\hline Asteraceae & Bellis perennis L. & $\mathrm{H}$ & 9 & 3 & $\mathrm{sp}$ & & \\
\hline Asteraceae & Bidens frondosa $\mathrm{L}$. & $\mathrm{T}$ & 12 & 3 & kn (inv) & N Am & \\
\hline Asteraceae & Calendula officinalis $\mathrm{L}$. & $\mathrm{T}$ & 1 & 5 & $\mathrm{df}$ & kultivar & \\
\hline Asteraceae & Centaurea jacea L. & $\mathrm{H}$ & 8 & 3 & $\mathrm{sp}$ & & \\
\hline Asteraceae & Cirsium arvense (L.) Scop. & G & 9 & 3 & $\mathrm{sp}$ & & \\
\hline Asteraceae & Cirsium oleraceum (L.) Scop. & $\mathrm{H}$ & 9 & 2 & $\mathrm{sp}$ & & \\
\hline Asteraceae & Cirsium vulgare (Savi) Ten. & $\mathrm{H}$ & 9 & 3 & $\mathrm{sp}$ & & \\
\hline Asteraceae & Conyza canadensis (L.) Cronquist & $\mathrm{T}$ & 12 & 5 & $\mathrm{kn}$ (inv) & NAm & \\
\hline Asteraceae & Doronicum austriacum Jacq. & G & 7 & 1 & $\mathrm{sp}$ & & \\
\hline Asteraceae & Erigeron annuus (L.) Pers. & $\mathrm{T}$ & 12 & 3 & kn (inv) & NAm & \\
\hline Asteraceae & Eupatorium cannabinum L. & $\mathrm{H}$ & 9 & 2 & $\mathrm{sp}$ & & \\
\hline Asteraceae & Galinsoga ciliata (Raf.) S.F.Blake & $\mathrm{T}$ & 12 & 4 & kn (inv) & CS Am & \\
\hline Asteraceae & Galinsoga parviflora Cav. & $\mathrm{T}$ & 12 & 4 & kn (inv) & $\mathrm{SAm}$ & \\
\hline Asteraceae & Helianthus annuus L. & $\mathrm{T}$ & 12 & 4 & $\mathrm{df}$ & NAm & \\
\hline Asteraceae & Inula conyza DC. & $\mathrm{H}$ & 9 & 2 & $\mathrm{sp}$ & & \\
\hline Asteraceae & Leucanthemum vulgare Lam. & $\mathrm{H}$ & 9 & 4 & $\mathrm{sp}$ & & \\
\hline Asteraceae & Matricaria perforata Merat & $\mathrm{T}$ & 9 & 4 & $\mathrm{sp}$ & & \\
\hline Asteraceae & $\begin{array}{l}\text { Petasites hybridus (L.) P.Gaertn, } \\
\text { B.Mey. et Schreb. }\end{array}$ & G & 9 & 2 & $\mathrm{sp}$ & & \\
\hline Asteraceae & Pulicaria dysenterica (L.) Bernh. & $\mathrm{T}$ & 9 & 3 & $\mathrm{sp}$ & & \\
\hline Asteraceae & Rudbeckia laciniata L. & G & 12 & 4 & kn (inv) & NAm & \\
\hline Asteraceae & Senecio jacobaea L. & $\mathrm{H}$ & 9 & 3 & $\mathrm{sp}$ & & \\
\hline
\end{tabular}


Appendix 1. continued

\begin{tabular}{|c|c|c|c|c|c|c|c|}
\hline Family & Taxon & $\begin{array}{l}\text { LIFE } \\
\text { FORM }\end{array}$ & $\begin{array}{l}\text { CHORO- } \\
\text { TYPE }\end{array}$ & $\begin{array}{l}\text { URB } \\
\text { INFL }\end{array}$ & ORIGIN & $\begin{array}{c}\text { GEO } \\
\text { ORIGIN }\end{array}$ & $\begin{array}{l}\text { END / TH / } \\
\text { PROTECT }\end{array}$ \\
\hline Asteraceae & Serratula tinctoria L. & $\mathrm{H}$ & 9 & 2 & $\mathrm{sp}$ & & \\
\hline Asteraceae & Solidago gigantea Aiton & $\mathrm{H}$ & 12 & 3 & kn (inv) & N Am & \\
\hline Asteraceae & Solidago virgaurea $\mathrm{L}$. & $\mathrm{H}$ & 9 & 2 & $\mathrm{sp}$ & & \\
\hline Asteraceae & Tanacetum vulgare $\mathrm{L}$. & $\mathrm{H}$ & 9 & 3 & $\mathrm{sp}$ & & \\
\hline Asteraceae & Tussilago farfara $\mathrm{L}$. & G & 9 & 3 & $\mathrm{sp}$ & & \\
\hline Berberidaceae & Berberis vulgaris L. & $\mathrm{P}$ & 8 & 3 & $\mathrm{sp}$ & & \\
\hline Betulaceae & Alnus glutinosa (L.) Gaertner & $\mathrm{P}$ & 9 & 1 & $\mathrm{sp}$ & & \\
\hline Betulaceae & Betula pendula Roth. & $\mathrm{P}$ & 9 & 3 & $\mathrm{sp}$ & & \\
\hline Boraginaceae & Cerinthe minor L. & $\mathrm{T}$ & 1 & 4 & $\mathrm{sp}$ & & \\
\hline Boraginaceae & Echium vulgare L. & $\mathrm{H}$ & 9 & 3 & $\mathrm{sp}$ & & \\
\hline Boraginaceae & Myosotis arvensis Hill & $\mathrm{T}$ & 9 & 4 & ar & E As Af & \\
\hline Boraginaceae & Myosotis ramosissima Rochel & $\mathrm{T}$ & 9 & 3 & $\mathrm{sp}$ & & \\
\hline Boraginaceae & Myosotis scorpioides L & $\mathrm{H}$ & 9 & 2 & $\mathrm{sp}$ & & \\
\hline Boraginaceae & Pulmonaria officinalis L. & $\mathrm{H}$ & 8 & 1 & $\mathrm{sp}$ & & \\
\hline Boraginaceae & Symphytum officinale L. & $\mathrm{H}$ & 9 & 3 & $\mathrm{sp}$ & & \\
\hline Boraginaceae & Symphytum tuberosum L. & G & 4 & 2 & $\mathrm{sp}$ & & \\
\hline Brassicaceae & Cardamine waldsteinii Dyer & G & 2 & 2 & $\mathrm{sp}$ & & endemic * \\
\hline Brassicaceae & Barbarea vulgaris R. Br. & $\mathrm{H}$ & 9 & 3 & $\mathrm{sp}$ & & \\
\hline Brassicaceae & Brassica rapa $\mathrm{L}$. & $\mathrm{T}$ & 1 & 5 & ar & E As Af & \\
\hline Brassicaceae & Capsella bursa-pastoris (L.) Medik. & $\mathrm{T}$ & 9 & 3 & ar & $E$ & \\
\hline Brassicaceae & Cardamine bulbifera (L.) Crantz & G & 8 & 2 & $\mathrm{sp}$ & & \\
\hline Brassicaceae & Cardamine hirsuta L. & $\mathrm{T}$ & 9 & 4 & ar & E As & \\
\hline Brassicaceae & Cardamine impatiens L. & $\mathrm{H}$ & 9 & 2 & $\mathrm{sp}$ & & \\
\hline Brassicaceae & Cardamine pratensis L. & $\mathrm{H}$ & 8 & 3 & $\mathrm{sp}$ & & \\
\hline Brassicaceae & Cardamine trifolia $\mathrm{L}$. & G & 3 & 2 & $\mathrm{sp}$ & & \\
\hline Brassicaceae & Lepidium campestre (L.) R. Br. & $\mathrm{T}$ & 9 & 4 & ar & E As & \\
\hline Brassicaceae & Lunaria rediviva $\mathrm{L}$. & $\mathrm{H}$ & 8 & 1 & $\mathrm{sp}$ & & \\
\hline Brassicaceae & Rorippa sylvestris (L.) Besser & $\mathrm{H}$ & 8 & 3 & $\mathrm{sp}$ & & \\
\hline Campanulaceae & Campanula patula L. & $\mathrm{H}$ & 8 & 3 & $\mathrm{sp}$ & & \\
\hline Campanulaceae & Campanula persicifolia L. & $\mathrm{H}$ & 8 & 3 & $\mathrm{sp}$ & & \\
\hline Campanulaceae & Campanula trachelium L. & $\mathrm{H}$ & 9 & 2 & $\mathrm{sp}$ & & \\
\hline Cannabaceae & Humulus lupulus L. & $\mathrm{H}$ & 9 & 3 & $\mathrm{sp}$ & & \\
\hline Caprifoliaceae & Sambucus ebulus L. & $\mathrm{H}$ & 9 & 2 & $\mathrm{sp}$ & & \\
\hline Caprifoliaceae & Sambucus nigra L. & $\mathrm{P}$ & 8 & 3 & $\mathrm{sp}$ & & \\
\hline Caryophyllaceae & $\begin{array}{l}\text { Cerastium fontanum Baumg. ssp. } \\
\text { vulgare (Hartman) Greuter et } \\
\text { Burdet }\end{array}$ & $\mathrm{H}$ & 9 & 3 & $\mathrm{sp}$ & & \\
\hline Caryophyllaceae & Cerastium glomeratum Thuill. & $\mathrm{T}$ & 9 & 5 & $\mathrm{sp}$ & & \\
\hline Caryophyllaceae & $\begin{array}{l}\text { Cerastium sylvaticum Waldst. et } \\
\text { Kit. }\end{array}$ & $\mathrm{H}$ & 5 & 2 & $\mathrm{sp}$ & & \\
\hline Caryophyllaceae & Dianthus armeria $\mathrm{L}$. & $\mathrm{H}$ & 9 & 5 & $\mathrm{sp}$ & & * \\
\hline Caryophyllaceae & Dianthus barbatus L. & $\mathrm{H}$ & 3 & 3 & $\mathrm{sp}$ & & * \\
\hline Caryophyllaceae & Lychnis flos-cuculi L. & $\mathrm{H}$ & 9 & 2 & $\mathrm{sp}$ & & \\
\hline Caryophyllaceae & Moehringia trinervia (L.) Clairv. & $\mathrm{H}$ & 9 & 2 & $\mathrm{sp}$ & & \\
\hline Caryophyllaceae & Myosoton aquaticum (L.) Moench & $\mathrm{H}$ & 9 & 3 & $\mathrm{sp}$ & & \\
\hline Caryophyllaceae & Silene dioica (L.) Clairv. & $\mathrm{H}$ & 8 & 3 & $\mathrm{sp}$ & & \\
\hline Caryophyllaceae & Silene latifolia Poir. & $\mathrm{T}$ & 1 & 2 & $\mathrm{sp}$ & & \\
\hline
\end{tabular}


Appendix 1. continued

\begin{tabular}{|c|c|c|c|c|c|c|c|}
\hline Family & Taxon & $\begin{array}{c}\text { LIFE } \\
\text { FORM }\end{array}$ & $\begin{array}{l}\text { CHORO- } \\
\text { TYPE }\end{array}$ & $\begin{array}{l}\text { URB } \\
\text { INFL }\end{array}$ & ORIGIN & $\begin{array}{c}\text { GEO } \\
\text { ORIGIN }\end{array}$ & $\begin{array}{l}\text { END / TH / } \\
\text { PROTECT }\end{array}$ \\
\hline Caryophyllaceae & $\begin{array}{l}\text { Silene latifolia Poir. ssp. alba (Mill.) } \\
\text { Greuter et Bourdet }\end{array}$ & $\mathrm{H}$ & 9 & 4 & ar & E As Af & \\
\hline Caryophyllaceae & Silene vulgaris (Moench.) Garcke & $\mathrm{H}$ & 8 & 3 & $\mathrm{sp}$ & & \\
\hline Caryophyllaceae & Stellaria graminea $\mathrm{L}$. & $\mathrm{H}$ & 9 & 2 & $\mathrm{sp}$ & & \\
\hline Caryophyllaceae & Stellaria holostea L. & $\mathrm{Ch}$ & 9 & 1 & $\mathrm{sp}$ & & \\
\hline Caryophyllaceae & Stellaria media (L.) Vill. & $\mathrm{T}$ & 9 & 4 & $\mathrm{sp}$ & & \\
\hline Celastraceae & Euonymus europaea L. & $\mathrm{P}$ & 9 & 2 & $\mathrm{sp}$ & & \\
\hline Celastraceae & Euonymus latifolius (L.) Mill. & $\mathrm{P}$ & 3 & 2 & $\mathrm{sp}$ & & \\
\hline Chenopodiaceae & Chenopodium album $\mathrm{L}$. & $\mathrm{T}$ & 9 & 5 & $\mathrm{sp}$ & & \\
\hline Cichoriaceae & Aposeris foetida (L.) Less. & $\mathrm{H}$ & 3 & 2 & $\mathrm{sp}$ & & \\
\hline Cichoriaceae & Cichorium intybus L. & $\mathrm{H}$ & 9 & 3 & ar & E As Af & \\
\hline Cichoriaceae & Crepis tectorum $\mathrm{L}$. & $\mathrm{T}$ & 9 & 5 & $\mathrm{sp}$ & & \\
\hline Cichoriaceae & $\begin{array}{l}\text { Crepis vesicaria L. ssp. taraxacifolia } \\
\text { (Thuill.) Thell. }\end{array}$ & $\mathrm{T}$ & 1 & 3 & $\mathrm{sp}$ & & \\
\hline Cichoriaceae & Hieracium murorum L. & $\mathrm{H}$ & 9 & 3 & $\mathrm{sp}$ & & \\
\hline Cichoriaceae & $\begin{array}{l}\text { Hieracium racemosum Waldst. et } \\
\text { Kit. ex Willd. }\end{array}$ & $\mathrm{H}$ & 3 & 2 & $\mathrm{sp}$ & & \\
\hline Cichoriaceae & Hieracium sabaudum L. & $\mathrm{H}$ & 8 & 3 & $\mathrm{sp}$ & & \\
\hline Cichoriaceae & Lactuca serriola L. & $\mathrm{T}$ & 9 & 4 & ar & E As Af & \\
\hline Cichoriaceae & $\begin{array}{l}\text { Leontodon hispidus L. ssp. } \\
\text { danubialis (Jacq.) Simonk. }\end{array}$ & $\mathrm{H}$ & 8 & 2 & $\mathrm{sp}$ & & \\
\hline Cichoriaceae & Mycelis muralis (L.) Dumort. & $\mathrm{H}$ & 9 & 3 & $\mathrm{sp}$ & & \\
\hline Cichoriaceae & Picris hieracioides L. & $\mathrm{H}$ & 9 & 3 & $\mathrm{sp}$ & & \\
\hline Cichoriaceae & Sonchus asper (L.) Hill & $\mathrm{T}$ & 9 & 3 & ar & E As Af & \\
\hline Cichoriaceae & Taraxacum officinale Weber & $\mathrm{H}$ & 9 & 3 & $\mathrm{sp}$ & & \\
\hline Cichoriaceae & Tragopogon pratensis L. & $\mathrm{H}$ & 4 & 3 & $\mathrm{sp}$ & & \\
\hline Clusiaceae & Hypericum perforatum $\mathrm{L}$. & $\mathrm{H}$ & 9 & 3 & $\mathrm{sp}$ & & \\
\hline Convolvulaceae & Calystegia sepium (L.) R. Br & $\mathrm{H}$ & 9 & 3 & $\mathrm{sp}$ & & \\
\hline Convolvulaceae & Convolvulus arvensis L. & G & 9 & 4 & ar & E As Af & \\
\hline Cornaceae & Cornus sanguinea L. & $\mathrm{P}$ & 8 & 4 & $\mathrm{sp}$ & & \\
\hline Corylaceae & Carpinus betulus L. & $\mathrm{P}$ & 9 & 2 & $\mathrm{sp}$ & & \\
\hline Corylaceae & Corylus avellana $\mathrm{L}$. & $\mathrm{P}$ & 8 & 3 & $\mathrm{sp}$ & & \\
\hline Corylaceae & Ostrya carpinifolia Scop. & $\mathrm{P}$ & 3 & 1 & $\mathrm{sp}$ & & \\
\hline Cucurbitaceae & $\begin{array}{l}\text { Echinocystis lobata (Michx.) Torr. } \\
\text { et Gray }\end{array}$ & $\mathrm{T}$ & 12 & 5 & kn (inv) & NAm & \\
\hline Dipsacaceae & Dipsacus fullonum L. & $\mathrm{H}$ & 9 & 4 & $\mathrm{sp}$ & & \\
\hline Dipsacaceae & Knautia arvensis (L.) Coult. & $\mathrm{H}$ & 9 & 3 & $\mathrm{sp}$ & & \\
\hline Dipsacaceae & Knautia drymeia Heuff. & $\mathrm{H}$ & 3 & 2 & $\mathrm{sp}$ & & \\
\hline Ericaceae & Calluna vulgaris (L.) Hull & $\mathrm{Ch}$ & 9 & 2 & $\mathrm{sp}$ & & \\
\hline Ericaceae & Vaccinium myrtillus L. & $\mathrm{Ch}$ & 9 & 2 & $\mathrm{sp}$ & & \\
\hline Euphorbiaceae & Euphorbia amygdaloides L. & $\mathrm{Ch}$ & 8 & 1 & $\mathrm{sp}$ & & \\
\hline Euphorbiaceae & Euphorbia angulata Jacq. & G & 3 & 1 & $\mathrm{sp}$ & & \\
\hline Euphorbiaceae & Euphorbia carniolica Jacq. & $\mathrm{H}$ & 2 & 1 & $\mathrm{sp}$ & & \\
\hline Euphorbiaceae & Euphorbia chamaesyce L. & $\mathrm{T}$ & 9 & 5 & $\mathrm{sp}$ & & \\
\hline Euphorbiaceae & Euphorbia cyparissias L. & $\mathrm{H}$ & 9 & 2 & $\mathrm{sp}$ & & \\
\hline Euphorbiaceae & Euphorbia dulcis L. & G & 5 & 1 & $\mathrm{sp}$ & & \\
\hline Euphorbiaceae & Euphorbia epithymoides Kern. & $\mathrm{H}$ & 6 & 1 & $\mathrm{sp}$ & & \\
\hline
\end{tabular}


Appendix 1. continued

\begin{tabular}{|c|c|c|c|c|c|c|c|}
\hline Family & Taxon & $\begin{array}{c}\text { LIFE } \\
\text { FORM }\end{array}$ & $\begin{array}{l}\text { CHORO- } \\
\text { TYPE }\end{array}$ & $\begin{array}{l}\text { URB } \\
\text { INFL }\end{array}$ & ORIGIN & $\begin{array}{c}\text { GEO } \\
\text { ORIGIN }\end{array}$ & $\begin{array}{l}\text { END / TH / } \\
\text { PROTECT }\end{array}$ \\
\hline Euphorbiaceae & Euphorbia helioscopia L. & $\mathrm{T}$ & 1 & 4 & ar & E As Af & \\
\hline Euphorbiaceae & Euphorbia platyphyllos L. & $\mathrm{T}$ & 1 & 3 & ar & E As & \\
\hline Euphorbiaceae & Euphorbia serrulata Thuill. & $\mathrm{T}$ & 9 & 2 & $\mathrm{sp}$ & & \\
\hline Euphorbiaceae & Euphorbia verrucosa $\mathrm{L}$. & $\mathrm{H}$ & 3 & 2 & $\mathrm{sp}$ & & \\
\hline Euphorbiaceae & Mercurialis perennis L. & $\mathrm{H}$ & 9 & 1 & $\mathrm{sp}$ & & \\
\hline Fabaceae & Anthyllis vulneraria L. & $\mathrm{H}$ & 4 & 3 & $\mathrm{sp}$ & & \\
\hline Fabaceae & Astragalus glycyphyllos L. & $\mathrm{H}$ & 9 & 2 & $\mathrm{sp}$ & & \\
\hline Fabaceae & Chamaecytisus supinus (L.) Link & $\mathrm{Ch}$ & 9 & 2 & $\mathrm{sp}$ & & \\
\hline Fabaceae & Coronilla varia $\mathrm{L}$. & $\mathrm{H}$ & 9 & 3 & $\mathrm{sp}$ & & \\
\hline Fabaceae & $\begin{array}{l}\text { Dorycnium germanicum (Gremli) } \\
\text { Rikli }\end{array}$ & $\mathrm{Ch}$ & 6 & 2 & $\mathrm{sp}$ & & \\
\hline Fabaceae & Dorycnium herbaceum Vill. & $\mathrm{H}$ & 6 & 2 & $\mathrm{sp}$ & & \\
\hline Fabaceae & Galega officinalis L. & $\mathrm{H}$ & 1 & 4 & ar & E & \\
\hline Fabaceae & Genista germanica L. & $\mathrm{Ch}$ & 8 & 2 & $\mathrm{sp}$ & & \\
\hline Fabaceae & Genista tinctoria $\mathrm{L}$. & $\mathrm{Ch}$ & 9 & 2 & $\mathrm{sp}$ & & \\
\hline Fabaceae & $\begin{array}{l}\text { Lathyrus linifolius (Reichard) } \\
\text { Bässler }\end{array}$ & $\mathrm{H}$ & 8 & 1 & $\mathrm{sp}$ & & \\
\hline Fabaceae & Lathyrus palustris L. & G & 10 & 2 & $\mathrm{sp}$ & & * \\
\hline Fabaceae & Lathyrus pratensis L. & $\mathrm{H}$ & 9 & 3 & $\mathrm{sp}$ & & \\
\hline Fabaceae & Lathyrus sylvestris L. & G & 8 & 3 & $\mathrm{sp}$ & & \\
\hline Fabaceae & Lathyrus tuberosus L. & $\mathrm{H}$ & 9 & 5 & ar & E As & \\
\hline Fabaceae & Lathyrus vernus (L.) Bernhardt & G & 9 & 1 & $\mathrm{sp}$ & & \\
\hline Fabaceae & Lembotropis nigricans (L.) Griseb. & $\mathrm{P}$ & 5 & 3 & $\mathrm{sp}$ & & \\
\hline Fabaceae & Lotus corniculatus L. & $\mathrm{H}$ & 9 & 3 & $\mathrm{sp}$ & & \\
\hline Fabaceae & Medicago falcata $\mathrm{L}$. & $\mathrm{H}$ & 9 & 3 & $\mathrm{sp}$ & & \\
\hline Fabaceae & Medicago lupulina $\mathrm{L}$. & $\mathrm{T}$ & 9 & 3 & $\mathrm{sp}$ & & \\
\hline Fabaceae & Medicago sativa $\mathrm{L}$. & $\mathrm{H}$ & 1 & 3 & $\mathrm{kn}$ & As & \\
\hline Fabaceae & Melilotus albus Medik. & $\mathrm{T}$ & 9 & 3 & ar & E As & \\
\hline Fabaceae & Melilotus officinalis (L.) Lam. & $\mathrm{H}$ & 9 & 4 & ar & E As & \\
\hline Fabaceae & Ononis arvensis L. & $\mathrm{H}$ & 5 & 2 & $\mathrm{sp}$ & & \\
\hline Fabaceae & Robinia pseudoacacia L. & $\mathrm{P}$ & 12 & 3 & kn (inv) & N Am & \\
\hline Fabaceae & Trifolium campestre Schreber & $\mathrm{T}$ & 1 & 2 & $\mathrm{sp}$ & & \\
\hline Fabaceae & Trifolium hybridum L. & $\mathrm{H}$ & 1 & 3 & $\mathrm{kn}$ & E As & \\
\hline Fabaceae & Trifolium medium L. & $\mathrm{H}$ & 9 & 2 & $\mathrm{sp}$ & & \\
\hline Fabaceae & Trifolium pratense $\mathrm{L}$. & $\mathrm{H}$ & 9 & 3 & $\mathrm{sp}$ & & \\
\hline Fabaceae & Trifolium repens L. & $\mathrm{H}$ & 9 & 4 & $\mathrm{sp}$ & & \\
\hline Fabaceae & Vicia angustifolia L. & $\mathrm{T}$ & 9 & 2 & ar & E As Af & \\
\hline Fabaceae & Vicia cassubica L. & $\mathrm{H}$ & 9 & 2 & $\mathrm{sp}$ & & \\
\hline Fabaceae & Vicia cracca L. & $\mathrm{H}$ & 9 & 2 & $\mathrm{sp}$ & & \\
\hline Fabaceae & Vicia dumetorum $\mathrm{L}$. & $\mathrm{H}$ & 8 & 1 & $\mathrm{sp}$ & & \\
\hline Fabaceae & Vicia hirsuta (L.) Gray & $\mathrm{T}$ & 9 & 4 & ar & E As Af & \\
\hline Fabaceae & Vicia sepium $\mathrm{L}$. & $\mathrm{H}$ & 8 & 3 & $\mathrm{sp}$ & & \\
\hline Fabaceae & Vicia villosa Roth & $\mathrm{T}$ & 1 & 4 & ar & E As & \\
\hline Fagaceae & Castanea sativa Miller & $\mathrm{P}$ & 1 & 2 & ar & E As & \\
\hline
\end{tabular}


Appendix 1. continued

\begin{tabular}{|c|c|c|c|c|c|c|c|}
\hline Family & Taxon & $\begin{array}{c}\text { LIFE } \\
\text { FORM }\end{array}$ & $\begin{array}{l}\text { CHORO- } \\
\text { TYPE }\end{array}$ & $\begin{array}{l}\text { URB } \\
\text { INFL }\end{array}$ & ORIGIN & $\begin{array}{c}\text { GEO } \\
\text { ORIGIN }\end{array}$ & $\begin{array}{l}\text { END / TH / } \\
\text { PROTECT }\end{array}$ \\
\hline Fagaceae & Fagus sylvatica L. & $\mathrm{P}$ & 8 & 1 & $\mathrm{sp}$ & & \\
\hline Fagaceae & Quercus cerris L. & $\mathrm{P}$ & 6 & 1 & $\mathrm{sp}$ & & \\
\hline Fagaceae & $\begin{array}{l}\text { Quercus petraea (Mattuschka) } \\
\text { Liebl. }\end{array}$ & $\mathrm{P}$ & 8 & 1 & $\mathrm{sp}$ & & \\
\hline Fagaceae & Quercus rubra L. & $\mathrm{P}$ & 12 & 2 & $\mathrm{df}$ & NAm & \\
\hline Gentianaceae & Centaurium erythraea Rafn & $\mathrm{T}$ & 9 & 2 & $\mathrm{sp}$ & & \\
\hline Gentianaceae & $\begin{array}{l}\text { Centaurium pulchellum (Sw.) } \\
\text { Druce }\end{array}$ & $\mathrm{T}$ & 9 & 3 & $\mathrm{sp}$ & & \\
\hline Gentianaceae & Gentiana asclepiadea L. & $\mathrm{H}$ & 7 & 2 & $\mathrm{sp}$ & & \\
\hline Geraniaceae & Geranium columbinum $\mathrm{L}$. & $\mathrm{T}$ & 9 & 4 & $\mathrm{sp}$ & & \\
\hline Geraniaceae & Geranium phaeum L. & $\mathrm{H}$ & 7 & 2 & $\mathrm{sp}$ & & \\
\hline Geraniaceae & Geranium pusillum Burm. f. & $\mathrm{T}$ & 9 & 4 & ar & E As & \\
\hline Geraniaceae & Geranium robertianum L. & $\mathrm{T}$ & 10 & 3 & $\mathrm{sp}$ & & \\
\hline Juglandaceae & Juglans regia $\mathrm{L}$. & $\mathrm{P}$ & 1 & 2 & $\mathrm{df}$ & E As & \\
\hline Lamiaceae & Ajuga reptans L. & $\mathrm{H}$ & 9 & 3 & $\mathrm{sp}$ & & \\
\hline Lamiaceae & Ballota nigra L. & $\mathrm{H}$ & 1 & 3 & ar & E As Af & \\
\hline Lamiaceae & Betonica officinalis L. & $\mathrm{H}$ & 1 & 2 & $\mathrm{sp}$ & & \\
\hline Lamiaceae & Clinopodium vulgare $\mathrm{L}$. & $\mathrm{H}$ & 9 & 2 & $\mathrm{sp}$ & & \\
\hline Lamiaceae & Galeopsis speciosa Mill. & $\mathrm{T}$ & 5 & 3 & $\mathrm{sp}$ & & \\
\hline Lamiaceae & Glechoma hirsuta Waldst. et Kit. & $\mathrm{H}$ & 6 & 3 & $\mathrm{sp}$ & & \\
\hline Lamiaceae & Lamium galeobdolon (L.) L. & $\mathrm{H}$ & 5 & 2 & $\mathrm{sp}$ & & \\
\hline Lamiaceae & Lamium maculatum L. & $\mathrm{H}$ & 8 & 3 & $\mathrm{sp}$ & & \\
\hline Lamiaceae & Lamium orvala $\mathrm{L}$. & $\mathrm{H}$ & 2 & 1 & $\mathrm{sp}$ & & \\
\hline Lamiaceae & Lamium purpureum $\mathrm{L}$. & $\mathrm{T}$ & 1 & 4 & ar & E As Af & \\
\hline Lamiaceae & Lycopus europaeus L. & G & 9 & 2 & $\mathrm{sp}$ & & \\
\hline Lamiaceae & Melittis melissophyllum L. & $\mathrm{H}$ & 8 & 2 & $\mathrm{sp}$ & & \\
\hline Lamiaceae & Mentha aquatica $\mathrm{L}$. & G & 9 & 2 & $\mathrm{sp}$ & & \\
\hline Lamiaceae & Mentha arvensis L. & $\mathrm{H}$ & 10 & 3 & $\mathrm{sp}$ & & \\
\hline Lamiaceae & Mentha longifolia (L.) Huds. & $\mathrm{H}$ & 9 & 2 & $\mathrm{sp}$ & & \\
\hline Lamiaceae & Mentha spicata L. & $\mathrm{H}$ & 3 & 4 & $\mathrm{sp}$ & & \\
\hline Lamiaceae & Origanum vulgare L. & $\mathrm{H}$ & 9 & 2 & $\mathrm{sp}$ & & \\
\hline Lamiaceae & Prunella vulgaris L. & $\mathrm{H}$ & 10 & 3 & $\mathrm{sp}$ & & \\
\hline Lamiaceae & Salvia glutinosa $\mathrm{L}$. & $\mathrm{H}$ & 9 & 1 & $\mathrm{sp}$ & & \\
\hline Lamiaceae & Salvia pratensis L. & $\mathrm{H}$ & 9 & 2 & $\mathrm{sp}$ & & \\
\hline Lamiaceae & Stachys palustris L. & $\mathrm{H}$ & 10 & 2 & $\mathrm{sp}$ & & \\
\hline Lamiaceae & Stachys sylvatica L. & $\mathrm{H}$ & 9 & 3 & $\mathrm{sp}$ & & \\
\hline Lamiaceae & Teucrium chamaedrys L. & $\mathrm{Ch}$ & 9 & 2 & $\mathrm{sp}$ & & \\
\hline Lamiaceae & Thymus pulegioides L. & $\mathrm{Ch}$ & 9 & 2 & $\mathrm{sp}$ & & \\
\hline Linaceae & Linum catharticum $\mathrm{L}$. & $\mathrm{T}$ & 9 & 2 & $\mathrm{sp}$ & & \\
\hline Loranthaceae & Viscum album L. & $\mathrm{P}$ & 8 & 2 & $\mathrm{sp}$ & & \\
\hline Lythraceae & Lythrum salicaria L. & $\mathrm{H}$ & 9 & 3 & $\mathrm{sp}$ & & \\
\hline Malvaceae & Malva sylvestris L. & $\mathrm{H}$ & 9 & 3 & ar & E As & \\
\hline Malvaceae & Malva moschata L. & $\mathrm{H}$ & 1 & 3 & $\mathrm{sp}$ & & \\
\hline Malvaceae & Malva alcea $\mathrm{L}$. & $\mathrm{H}$ & 3 & 3 & $\mathrm{sp}$ & & \\
\hline
\end{tabular}


Appendix 1. continued

\begin{tabular}{|c|c|c|c|c|c|c|c|}
\hline Family & Taxon & $\begin{array}{c}\text { LIFE } \\
\text { FORM }\end{array}$ & $\begin{array}{l}\text { CHORO- } \\
\text { TYPE }\end{array}$ & $\begin{array}{l}\text { URB } \\
\text { INFL }\end{array}$ & ORIGIN & $\begin{array}{c}\text { GEO } \\
\text { ORIGIN }\end{array}$ & $\begin{array}{l}\text { END / TH / } \\
\text { PROTECT }\end{array}$ \\
\hline Oleaceae & Ligustrum vulgare L. & $P$ & 9 & 2 & $\mathrm{sp}$ & & \\
\hline Oleaceae & Fraxinus ornus L. & $\mathrm{P}$ & 9 & 2 & $\mathrm{sp}$ & & \\
\hline Onagraceae & Circaea lutetiana $\mathrm{L}$. & G & 9 & 3 & $\mathrm{sp}$ & & \\
\hline Onagraceae & $\begin{array}{l}\text { Epilobium tetragonum L. ssp. lamyi } \\
\text { (F. W. Schultz) Nyman }\end{array}$ & $\mathrm{H}$ & 8 & 2 & $\mathrm{sp}$ & & \\
\hline Onagraceae & Epilobium tetragonum $\mathrm{L}$. & $\mathrm{H}$ & 9 & 3 & $\mathrm{sp}$ & & \\
\hline Onagraceae & Epilobium hirsutum L. & $\mathrm{H}$ & 9 & 3 & $\mathrm{sp}$ & & \\
\hline Onagraceae & Epilobium montanum L. & $\mathrm{H}$ & 9 & 3 & $\mathrm{sp}$ & & \\
\hline Onagraceae & $\begin{array}{l}\text { Epilobium lanceolatum Sebast. et } \\
\text { Mauri }\end{array}$ & $\mathrm{H}$ & 9 & 3 & $\mathrm{sp}$ & & \\
\hline Onagraceae & Epilobium parviflorum Schreber & $\mathrm{H}$ & 8 & 3 & $\mathrm{sp}$ & & \\
\hline Orobanchaceae & Orobanche lutea Baumg. & $\mathrm{T}$ & 9 & 3 & $\mathrm{sp}$ & & \\
\hline Orobanchaceae & Orobanche major $\mathrm{L}$. & $\mathrm{T}$ & 9 & 2 & $\mathrm{sp}$ & & \\
\hline Oxalidaceae & Oxalis acetosella $\mathrm{L}$. & $\mathrm{H}$ & 9 & 1 & $\mathrm{sp}$ & & \\
\hline Oxalidaceae & Oxalis dillenii Jacq. & $\mathrm{T}$ & 12 & 4 & $\mathrm{kn}$ & N Am & \\
\hline Papaveraceae & Chelidonium majus L. & $\mathrm{H}$ & 9 & 3 & ar & E As & \\
\hline Papaveraceae & Papaver rhoeas L. & $\mathrm{T}$ & 9 & 4 & ar & E As Af & \\
\hline Plantaginaceae & Plantago lanceolata $\mathrm{L}$. & $\mathrm{H}$ & 9 & 3 & $\mathrm{sp}$ & & \\
\hline Plantaginaceae & Plantago major $\mathrm{L}$. & $\mathrm{H}$ & 9 & 3 & $\mathrm{sp}$ & & \\
\hline Polygalaceae & Polygala vulgaris $\mathrm{L}$. & $\mathrm{H}$ & 8 & 2 & $\mathrm{sp}$ & & \\
\hline Polygonaceae & Polygonum mite Schrank & $\mathrm{T}$ & 8 & 2 & $\mathrm{sp}$ & & \\
\hline Polygonaceae & Polygonum persicaria $\mathrm{L}$. & $\mathrm{T}$ & 11 & 3 & $\mathrm{sp}$ & & \\
\hline Polygonaceae & Rumex acetosa $\mathrm{L}$. & $\mathrm{H}$ & 9 & 3 & $\mathrm{sp}$ & & \\
\hline Polygonaceae & Rumex acetosella $\mathrm{L}$. & $\mathrm{H}$ & 10 & 3 & $\mathrm{sp}$ & & \\
\hline Polygonaceae & Rumex conglomeratus Murray & $\mathrm{H}$ & 9 & 2 & $\mathrm{sp}$ & & \\
\hline Polygonaceae & Rumex crispus L. & $\mathrm{H}$ & 9 & 4 & $\mathrm{sp}$ & & \\
\hline Polygonaceae & Rumex obtusifolius L. & $\mathrm{H}$ & 8 & 3 & $\mathrm{sp}$ & & \\
\hline Polygonaceae & Rumex patientia $\mathrm{L}$. & $\mathrm{H}$ & 1 & 4 & $\mathrm{sp}$ & & \\
\hline Polygonaceae & Rumex sanguineus L. & $\mathrm{H}$ & 9 & 2 & $\mathrm{sp}$ & & \\
\hline Primulaceae & Anagallis arvensis $\mathrm{L}$. & $\mathrm{T}$ & 1 & 4 & ar & E As Af & \\
\hline Primulaceae & Cyclamen purpurascens Mill. & G & 3 & 2 & $\mathrm{sp}$ & & \\
\hline Primulaceae & Lysimachia nummularia $\mathrm{L}$. & $\mathrm{Ch}$ & 8 & 2 & $\mathrm{sp}$ & & \\
\hline Primulaceae & Lysimachia punctata L. & $\mathrm{H}$ & 5 & 3 & $\mathrm{sp}$ & & \\
\hline Primulaceae & Lysimachia vulgaris L. & $\mathrm{H}$ & 9 & 2 & $\mathrm{sp}$ & & \\
\hline Primulaceae & Primula vulgaris Huds. & $\mathrm{H}$ & 9 & 3 & $\mathrm{sp}$ & & \\
\hline Ranunculaceae & Anemone nemorosa $\mathrm{L}$. & G & 8 & 2 & $\mathrm{sp}$ & & \\
\hline Ranunculaceae & Caltha palustris L. & $\mathrm{H}$ & 10 & 2 & $\mathrm{sp}$ & & \\
\hline Ranunculaceae & Clematis vitalba $\mathrm{L}$. & $\mathrm{P}$ & 8 & 2 & $\mathrm{sp}$ & & \\
\hline Ranunculaceae & Hepatica nobilis Schreber & $\mathrm{H}$ & 8 & 2 & $\mathrm{sp}$ & & \\
\hline Ranunculaceae & Ranunculus acris L. & $\mathrm{H}$ & 9 & 3 & $\mathrm{sp}$ & & \\
\hline Ranunculaceae & Ranunculus arvensis L. & $\mathrm{T}$ & 1 & 4 & ar & E As Af & \\
\hline Ranunculaceae & Ranunculus bulbosus L. & $\mathrm{H}$ & 9 & 3 & $\mathrm{sp}$ & & \\
\hline Ranunculaceae & Ranunculus repens L. & $\mathrm{H}$ & 9 & 3 & $\mathrm{sp}$ & & \\
\hline Ranunculaceae & Thalictrum flavum L. & $\mathrm{H}$ & 8 & 2 & $\mathrm{sp}$ & & \\
\hline Rhamnaceae & Frangula alnus Mill. & $\mathrm{P}$ & 9 & 1 & $\mathrm{sp}$ & & \\
\hline
\end{tabular}


Appendix 1. continued

\begin{tabular}{|c|c|c|c|c|c|c|c|}
\hline Family & Taxon & $\begin{array}{c}\text { LIFE } \\
\text { FORM }\end{array}$ & $\begin{array}{c}\text { CHORO- } \\
\text { TYPE }\end{array}$ & $\begin{array}{l}\text { URB } \\
\text { INFL }\end{array}$ & ORIGIN & $\begin{array}{c}\text { GEO } \\
\text { ORIGIN }\end{array}$ & $\begin{array}{l}\text { END / TH / } \\
\text { PROTECT }\end{array}$ \\
\hline Rosaceae & Agrimonia eupatoria L. & $\mathrm{H}$ & 9 & 2 & $\mathrm{sp}$ & & \\
\hline Rosaceae & Aruncus dioicus (Walter) Fernald & $\mathrm{H}$ & 10 & 2 & $\mathrm{sp}$ & & \\
\hline Rosaceae & Crataegus monogyna Jacq. & $\mathrm{P}$ & 9 & 2 & $\mathrm{sp}$ & & \\
\hline Rosaceae & Filipendula ulmaria (L.) Maxim. & $\mathrm{H}$ & 9 & 2 & $\mathrm{sp}$ & & \\
\hline Rosaceae & Fragaria moschata Duchesne & $\mathrm{H}$ & 8 & 3 & $\mathrm{sp}$ & & \\
\hline Rosaceae & Fragaria vesca L. & $\mathrm{H}$ & 9 & 3 & $\mathrm{sp}$ & & \\
\hline Rosaceae & Geum urbanum L. & $\mathrm{H}$ & 9 & 3 & $\mathrm{sp}$ & & \\
\hline Rosaceae & Malus pumila Mill. & $\mathrm{P}$ & 12 & 5 & $\mathrm{df}$ & kultivar & \\
\hline Rosaceae & Malus sylvestris Mill. & $\mathrm{P}$ & 8 & 3 & & & \\
\hline Rosaceae & Potentila reptans $\mathrm{L}$. & $\mathrm{H}$ & 9 & 3 & $\mathrm{sp}$ & & \\
\hline Rosaceae & Potentilla erecta (L.) Raeuschel & $\mathrm{H}$ & 9 & 2 & $\mathrm{sp}$ & & \\
\hline Rosaceae & Prunus avium L. & $\mathrm{P}$ & 9 & 3 & $\mathrm{sp}$ & & \\
\hline Rosaceae & Prunus cerasifera Ehrh. & $\mathrm{P}$ & 9 & 3 & $\mathrm{kn}$ & E As & \\
\hline Rosaceae & Prunus domestica $\mathrm{L}$. & $\mathrm{P}$ & 9 & 4 & ar & E As & \\
\hline Rosaceae & Pyrus pyraster Burgsd. & $\mathrm{P}$ & 9 & 1 & $\mathrm{sp}$ & & \\
\hline Rosaceae & Rosa canina $\mathrm{L}$. & $\mathrm{P}$ & 9 & 2 & $\mathrm{sp}$ & & \\
\hline Rosaceae & Rubus idaeus L. & $\mathrm{P}$ & 9 & 3 & $\mathrm{sp}$ & & \\
\hline Rosaceae & Rubus plicatus Weihe et Nees & $\mathrm{P}$ & 4 & 1 & $\mathrm{sp}$ & & \\
\hline Rosaceae & Sorbus aria (L.) Crantz & $\mathrm{P}$ & 8 & 2 & $\mathrm{sp}$ & & \\
\hline Rosaceae & Sorbus torminalis (L.) Crantz & $\mathrm{P}$ & 9 & 1 & $\mathrm{sp}$ & & \\
\hline Rubiaceae & Crutiata laevipes Opiz. & $\mathrm{H}$ & 8 & 3 & $\mathrm{sp}$ & & \\
\hline Rubiaceae & Galium album Mill. & $\mathrm{H}$ & 9 & 3 & $\mathrm{sp}$ & & \\
\hline Rubiaceae & Galium aparine $\mathrm{L}$. & $\mathrm{T}$ & 9 & 3 & $\mathrm{sp}$ & & \\
\hline Rubiaceae & Galium mollugo L. & $\mathrm{H}$ & 8 & 2 & $\mathrm{sp}$ & & \\
\hline Rubiaceae & Galium odoratum (L.) Scop. & G & 9 & 1 & $\mathrm{sp}$ & & \\
\hline Rubiaceae & Galium sylvaticum L. & G & 8 & 1 & $\mathrm{sp}$ & & \\
\hline Rubiaceae & Galium verum $\mathrm{L}$. & $\mathrm{H}$ & 9 & 3 & $\mathrm{sp}$ & & \\
\hline Salicaceae & Populus nigra L. & $\mathrm{P}$ & 9 & 2 & $\mathrm{sp}$ & & \\
\hline Salicaceae & Populus tremula $\mathrm{L}$ & $\mathrm{P}$ & 9 & 2 & $\mathrm{sp}$ & & \\
\hline Salicaceae & Salix alba $\mathrm{L}$. & $\mathrm{P}$ & 9 & 3 & $\mathrm{sp}$ & & \\
\hline Salicaceae & Salix caprea L. & $\mathrm{P}$ & 9 & 3 & $\mathrm{sp}$ & & \\
\hline Salicaceae & Salix cinerea $\mathrm{L}$ & $\mathrm{P}$ & 9 & 2 & $\mathrm{sp}$ & & \\
\hline Salicaceae & Salix purpurea $\mathrm{L}$. & $\mathrm{P}$ & 9 & 2 & $\mathrm{sp}$ & & \\
\hline Salicaceae & Salix triandra $\mathrm{L}$. & $\mathrm{P}$ & 8 & 2 & $\mathrm{sp}$ & & \\
\hline Scrophulariaceae & Digitalis grandiflora Mill. & G & 9 & 2 & $\mathrm{sp}$ & & \\
\hline Scrophulariaceae & Linaria vulgaris Mill. & $\mathrm{H}$ & 9 & 4 & $\mathrm{sp}$ & & \\
\hline Scrophulariaceae & Melampyrum pratense $\mathrm{L}$ & $\mathrm{T}$ & 9 & 2 & $\mathrm{sp}$ & & \\
\hline Scrophulariaceae & Odontites vulgaris Moench & $\mathrm{T}$ & 9 & 3 & $\mathrm{sp}$ & & \\
\hline Scrophulariaceae & Rhinanthus minor L. & $\mathrm{T}$ & 9 & 2 & $\mathrm{sp}$ & & \\
\hline Scrophulariaceae & Verbascum blattaria L. & $\mathrm{H}$ & 9 & 3 & $\mathrm{sp}$ & & \\
\hline Scrophulariaceae & Verbascum nigrum L. & $\mathrm{H}$ & 9 & 3 & $\mathrm{sp}$ & & \\
\hline Scrophulariaceae & Veronica chamaedrys L. & $\mathrm{H}$ & 9 & 3 & $\mathrm{sp}$ & & \\
\hline Scrophulariaceae & Veronica officinalis L. & $\mathrm{Ch}$ & 8 & 2 & $\mathrm{sp}$ & & \\
\hline Scrophulariaceae & Veronica persica Poir. & $\mathrm{T}$ & 12 & 4 & kn (inv) & As & \\
\hline
\end{tabular}


Appendix 1. continued

\begin{tabular}{|c|c|c|c|c|c|c|c|}
\hline Family & Taxon & $\begin{array}{l}\text { LIFE } \\
\text { FORM }\end{array}$ & $\begin{array}{c}\text { CHORO- } \\
\text { TYPE }\end{array}$ & $\begin{array}{l}\text { URB } \\
\text { INFL }\end{array}$ & ORIGIN & $\begin{array}{c}\text { GEO } \\
\text { ORIGIN }\end{array}$ & $\begin{array}{l}\text { END / TH / } \\
\text { PROTECT }\end{array}$ \\
\hline Scrophulariaceae & Veronica polita Fr. & $\mathrm{T}$ & 1 & 4 & ar & E As Af & \\
\hline Solanaceae & Solanum nigrum L. & $\mathrm{T}$ & 10 & 4 & ar & $E$ & \\
\hline Thymelaeaceae & Daphne laureola $\mathrm{L}$. & $\mathrm{P}$ & 4 & 1 & $\mathrm{sp}$ & & \\
\hline Thymelaeaceae & Daphne mezereum L. & $\mathrm{P}$ & 9 & 1 & $\mathrm{sp}$ & & \\
\hline Tiliaceae & Tilia cordata Mill. & $\mathrm{P}$ & 8 & 2 & $\mathrm{sp}$ & & \\
\hline Tiliaceae & Tilia platyphyllos Scop. & $\mathrm{P}$ & 8 & 2 & $\mathrm{sp}$ & & \\
\hline Tiliaceae & Tilia tomentosa Moench & $\mathrm{P}$ & 6 & 4 & $\mathrm{sp}$ & & \\
\hline Urticaceae & Urtica dioica $\mathrm{L}$. & $\mathrm{H}$ & 9 & 3 & $\mathrm{sp}$ & & \\
\hline Valerianaceae & Valeriana officinalis L. & $\mathrm{H}$ & 5 & 2 & $\mathrm{sp}$ & & \\
\hline Verbenaceae & Verbena officinalis L. & $\mathrm{H}$ & 9 & 4 & ar & E As Af & \\
\hline Violaceae & $\begin{array}{l}\text { Viola reichenbachiana Jord. ex } \\
\text { Boreau }\end{array}$ & $\mathrm{H}$ & 8 & 3 & $\mathrm{sp}$ & & \\
\hline Vitaceae & $\begin{array}{l}\text { Vitis vinifera L. ssp. sylvestris (C. C. } \\
\text { Gmel.) Hegi }\end{array}$ & P & 9 & 3 & ar & E As & \\
\hline Vitaceae & Vitis vinifera $\mathrm{L}$. & $\mathrm{P}$ & 9 & 4 & $\mathrm{df}$ & E As & \\
\hline
\end{tabular}

